\title{
Developing two benchmark models for nearly zero energy schools
}

\author{
Shady Attia ${ }^{\mathrm{a}, *}$, Niloufar Shadmanfar ${ }^{\mathrm{a}, \mathrm{b}}$, Federico Ricci ${ }^{\mathrm{a}, \mathrm{c}}$ \\ ${ }^{a}$ Sustainable Building Design Lab, Dept. UEE, Faculty of Applied Science, Université de Liège, Belgium \\ ${ }^{\mathrm{b}}$ Dipartimento di Architettura, Ingegneria delle Costruzioni e Ambiente Costruito, Politecnoco Di Milano, Italy \\ ${ }^{\mathrm{c}}$ Scuola Politecnica, Universita degli studi di Genova, Italy
}

\section{H I G H L I G H T S}

- Development of two Belgian benchmark models for nearly Zero Energy Schools.

- Average energy use intensity per school (primary and secondary) was 59 and $42 \mathrm{kWh} / \mathrm{m}^{2} /$ year.

- Models validated with four-year monitoring data on energy consumption.

- Nearly Zero Energy Schools needs are cooling and electricity dominated.

- Findings on energy needs and use intensity are useful in temperate and continental climates.

\section{A R T I C L E I N F O}

\section{Keywords:}

Reference building

Nearly zero energy building

Energy audit

Energy efficiency

Energy use intensity

Temperate climate
G R A P H I C A L A B S T R A C T

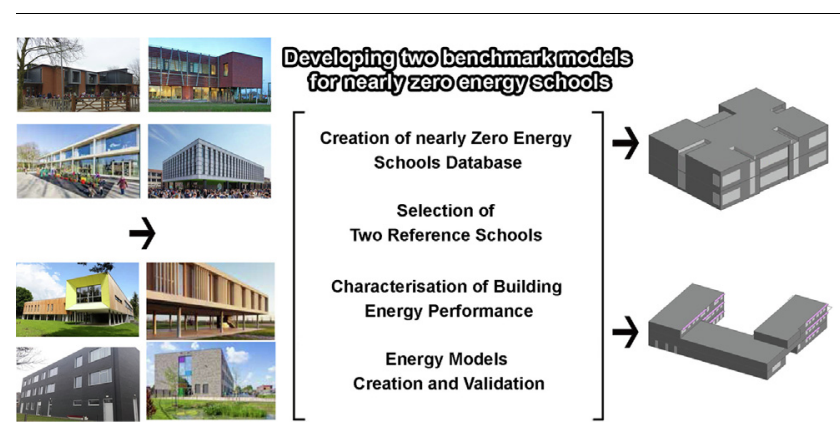

\begin{abstract}
A B S T R A C T
The aim of this study is to develop an energy performance data set and two building performance simulation benchmark models for high performance schools in Belgium. The study reports the results of an inventory and field survey conducted on nearly Zero Energy Schools (nZES) and Passive House Schools (PHS) constructed after year 2013. An analysis of energy consumption (electricity and natural gas) and a walkthrough survey were conducted during May 2018. The energy consumption analysis was done for the occupancy period of 2015-2018 based on monthly consumption data. Two building performance simulation models are created in EnergyPlus to benchmark the average energy consumption and building characteristics. The validity of the estimate has been further checked against the public statistics and verified through model calibration and utility bill comparison. The paper provides a timely opportunity to evaluate the real performance of nZES, in relation to design assumptions and how schools' professionals can turn the energy performance gap challenge to their advantage. The findings on energy needs and use intensity are useful in temperate and continental climates.
\end{abstract}

\footnotetext{
Abbreviations: ANN, Artificial Neural Networks BPIE, Building Performance Institute Europe; BMS, Building Management System; CAV, Constant Air Volume; CDD,

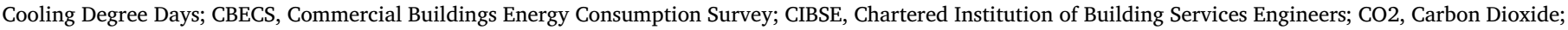

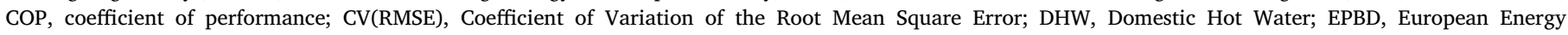

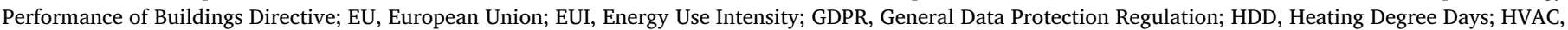

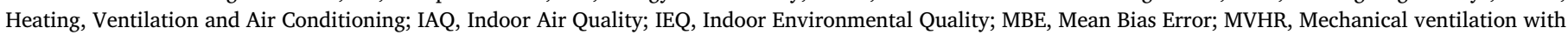

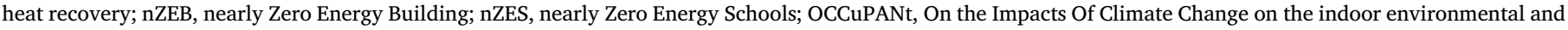

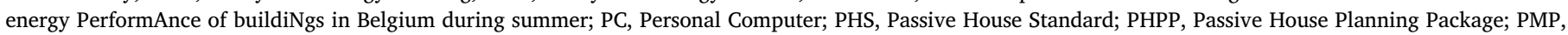

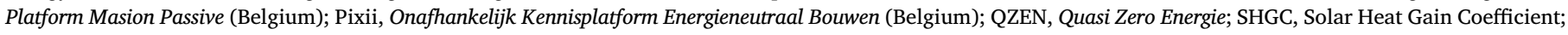

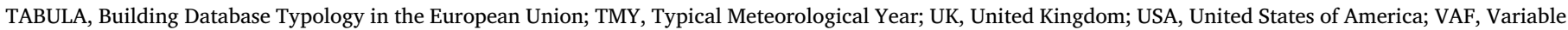
Air Flow; WWR, Window to Wall Ratio; ZEBRA 2020, nearly Zero-Energy Building Strategy 2020

*Corresponding author at: University of Liège, Faculty of Applied Science, Dept. UEE, SBD Lab: Office + 0/542, Quartier Polytech 1, Allée de la Découverte 13A, 4000 Liège, Belgium.

E-mail addresses: shady.attia@uliege.be (S. Attia),n.shadmanfar@gmail.com (N. Shadmanfar), fede1ricci@gmail.com (F. Ricci).
} 


\section{Introduction}

The European Energy Performance of Buildings Directive (EPBD) requires all new buildings (public buildings from 2019) to be nearly zero-energy buildings (nZEB) by 31 December 2020. Already since 31 December 2018, new buildings occupied and owned by public authorities should be nZEB. This is a result of a long incremental regulation evolution starting with the EPBD 2010 [1] and ending with the EU Directive 2018/844 of the European Parliament [2] and the Council of 30 May 2018, who amended the Directive 2010/31/EU on the energy performance of buildings and the Directive 2012/27/EU on energy efficiency. The nearly zero or very low amount of energy required should be covered to a very significant extent from renewable sources, including sources produced on-site or nearby. For the building sector, this implies the large scale deployment of nearly Zero-Energy Buildings (nZEBs). Combining renewable energy and resource efficiency can play an important role in the transition of the European society and economy towards sustainability and carbon neutrality [3].

One of the fastest growing sectors in Europe is educational buildings. According to Eurostat data (2018), the annual student population growth rate is expected to be around 3 percent until 2050. Before 2050, all member states will need to assure a minimum floor area growth of $0.5 \%$. This means that at least 4 million square meters of new classrooms space. This figure represents more than 40,000 new classrooms. All these new classrooms need to be integrated into new schools in addition to the schools that needs to be renovated require innovative energy saving and indoor environmental quality solutions to demonstrate a commitment to reducing climate impacts, lower energy cost and over time save money on energy bills that can be spent on almost 100 million students [4].

Several national and regional governments have a target date of 2021 for every new school to be actively working on becoming energy neutral. Like every European Union (EU) member state, Belgium had to source $20 \%$ of its energy from renewable sources by 2020 . Therefore, school buildings represent a significant part of the buildings stock. As shown in Fig. 1, education buildings are responsible of 1.5 percent of Belgium's greenhouse gas emissions. In Belgium (2017), almost 3 million people attend one of the 6000 schools every day. Two regional governments decided to be front runners with nearly zero energy schools (nZES) [5]. In 2008, the Flemish gave the green light to the 'Passive Schools Pilot Project: building schools according to the Passive
House standard spread across all provinces and educational networks in Flanders. This corresponds to a total construction area of $65,565 \mathrm{~m} 2$. Herewith, the Flemish Government wanted to anticipate in time the transition to highly energy-efficient school buildings and the strict European regulations that were still being drafted [6]. Similarly, in 2009 the Brussels government passed an order imposing the passive standard on all regional new public buildings by 2010 , and on May 3 , 2011 adopted new energy target regulation for all new construction (housing, offices and schools) by 2015. The EPBD recast directive imposed the nearly zero energy standard, and the passive standard became an important first step towards achieving the zero energy schools. It was until 2017, when the government of Wallonia, the third region of Belgium, decided to adopt the same approach in Flanders and Brussels Regions.

As a result of those initiatives and projects, the Passive House concept was strongly adopted in Belgium and evolved to be nearly Zero Energy Building concept (BEN-'Bijna-energieneutraal' and Q-ZEN-'Quasi Zéro Energie') [7]. And, between 2013 and 2019, more than 50 new nZES were constructed. However, local governments [8], building professionals and scientist are challenged by how to evaluate those new schools [9]. Several international state agencies seek to build and assure the performance of green healthy schools including, for example, Belgium [10], Chile [11], Greece [12] and the Netherlands [13]. nZES are high-tech buildings that try balance the high indoor air quality and comfort conditions while keeping the ultra-low energy use target [14]. The determination of the boundary conditions and design strategies and solutions for those schools remains challenging [15]. In the same time, little effort was made to assess those school buildings and benchmark their performance [13].

The concept of 'reference building' has been introduced by the EPBD-recast [1] for the development of a reference building that represents the typical and average building of the stock [16]. According to the Commission Guidelines accompanying the Commission Delegated Regulation No. 244 (2012) [17], it is recommended that reference buildings are established representing the most typical building in a specific category (e.g. type of use and reference occupancy pattern or floor area or building envelope construction etc.). Several examples of benchmarking studies for education building already exist including the work of Khoshbakht 2018 in Australia [18], Pereira 2017 in Portugal [19], Thewes 2014 [20] in Luxembourg, Kim 2012 in South Korea [21], Dascalaki. 2011 [16], Dimoudi. 2009 [22] and Martinopoulos in
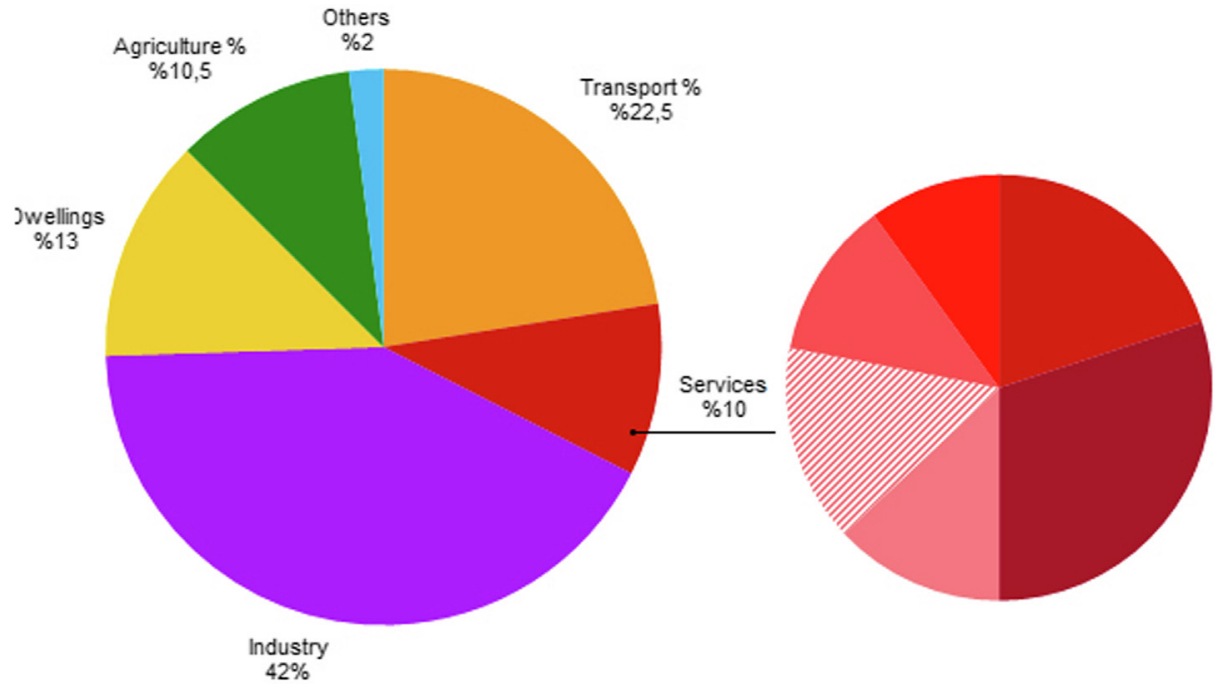

- Trade $2 \%$

- Office $3 \%$

- Service $1.3 \%$

\% Educational $1.5 \%$

घ Health $1.2 \%$

- Catering $1 \%$

Fig. 1. Greenhouse gas emissions of Belgium in 2017 [4]. 
Greece [23], and Hernandez. 2008 in Ireland [24]. Yet, none of those studies addressed benchmarking nZES based on a wide-set of building data. Despite the wide use of the Commercial Buildings Energy Consumption Survey (CBECS) database in the USA [25] and the TABULA building typology database in EU, there is no database for nZES [26].

Thus, a substantial knowledge gap in reliable benchmark models for high performance schools makes it difficult for policy-makers and building professionals worldwide to evaluate the success of their policies and designs [24]. Several European Member states do not have historical data for schools energy performance or benchmark models for evaluating building energy performance [27]. Therefore, the aim of this paper is to understand and characterize the energy performance of nearly zero energy schools by developing a benchmark model. The first objective of this study is to conduct a field survey that reports building characteristics and end use energy pattern and energy cost. The second objective is creating a valid and up-to-date benchmark model of nearly zero energy schools in Belgium. Despite the acknowledged importance of building benchmarks and their validity, in literature [28], so far only limited attention has been paid to establish robust, credible and simple building performance models [29].

By reviewing literature we can distinguish two groups of publications that addressed benchmarking of building's performance [30]. The first group entails studies that aimed to characterize buildings around clusters of similar performance using advanced clustering analysis methods based on large samples of observations/buildings [31]. For example, Santamouris 2007 used a fuzzy clustering technique to analyze 320 schools in Greece [32]. The examined schools were built between 1979 and 1996 and focused on identified the Energy Use Intensity (EUI) and indoor environmental quality (IEQ). Gao 2014, proposed a new clustering methodology using a machine learning algorithm to classify buildings based on 1964 observation/building sample from the United States of America Commercial Buildings Energy Consumption Survey (CBECS) [33]. The study focused mainly on testing the methodology in comparison to the Energy Star approach. Similarly, Papadopoulos 2018 conducted a cluster analysis of approximately 15,000 properties in New York between 2011 and 2016 [34]. Using a learning algorithm two distinct temporal patterns of energy performance for commercial and residential buildings were identified. Also, the study of Hong 2014 belongs to this group one because statistical methods in combination with artificial neural networks (ANN) were used to identify the factor that have significant impact on energy use in schools [35]. However, this study did not perform a clustering analysis. The statistical analysis was performed for approximately 7700 schools and ANN analysis was performed for 465 schools. The study was based on an extremely large sample of schools constructed between 1860 and 2010 in the United Kingdom.
The second group of publications entails studies that aimed to characterize building using general statistical methods. For example, Luo (2017) developed a general statistical method using 24-h electric load shapes of over 2000 small-and medium-sized businesses for benchmarking [36]. The study focused on identifying a representative building load. The load shape benchmarking was the final outcome of this study for cooling dominated buildings in California, USA. Similarly, Park (2016) used various statistical techniques based on data collected from 1072 office buildings in South Korea [37]. The results grouped the buildings under six categories. Also, Marrone (2018) created an energy benchmark for educations buildings in Italy through cluster analysis of energy retrofitting [38]. The study was based on 80 refurbished school buildings and focused mainly on renovation measures.

The two groups of publications presented above represent studies that aimed to characterize buildings according to similarity. However, they did not aim to create full descriptions or present building performance simulation benchmark models. Also, none of the presented studies addressed high performance schools. Despite the study of Santamouris (2007) and Hong (2014) [35] who focused on schools, both studies did not address nZES [32]. Considering the overview of literature, it is clear that are currently no available building simulation benchmark models for nZES.

In this paper, we present two simulation reference models created based on monitoring and analyzing 30 high performance schools in Belgium. Our study approach and methodology is similar to the work of Hernandez (2007) [24], Torcellini (2008) [39], and Attia (2012) [40] aiming to develop two benchmark buildings that represent most of newly built school building stock, representing the climate of Belgium between 2015 and 2018. The reference models are documented and implemented to use with the EnergyPlus energy simulation program. Although the authors are aware of the importance of indoor environmental quality issues in nZES buildings, they were not considered in this paper. The indoor environmental quality evaluation of nZES is a large field of investigation that we opted to address separately in a future study. Therefore, this study focuses on benchmarking energy use in high performance schools in Belgium.

In the same time, the paper provides valuable contribution to the new body of knowledge from the international perspective.). The study is useful for cities that are heating dominated such as Brussels, which had 2381 Heating Degree Days (HDD) and 38 Cooling Degree Days (CDD), in 2018 [41]. The study provides insights on the energy performance discrepancies of nearly Zero Energy Schools in cold and mild temperate climates ( $\mathrm{Cfb}=$ Temperate oceanic climate) as-well-as continental climates ( $\mathrm{Dfb}=$ Warm-summer humid continental climate) according to Köppen climate classification (see Fig. 2). Cities falling in those two regions will be able to improve their understanding of the

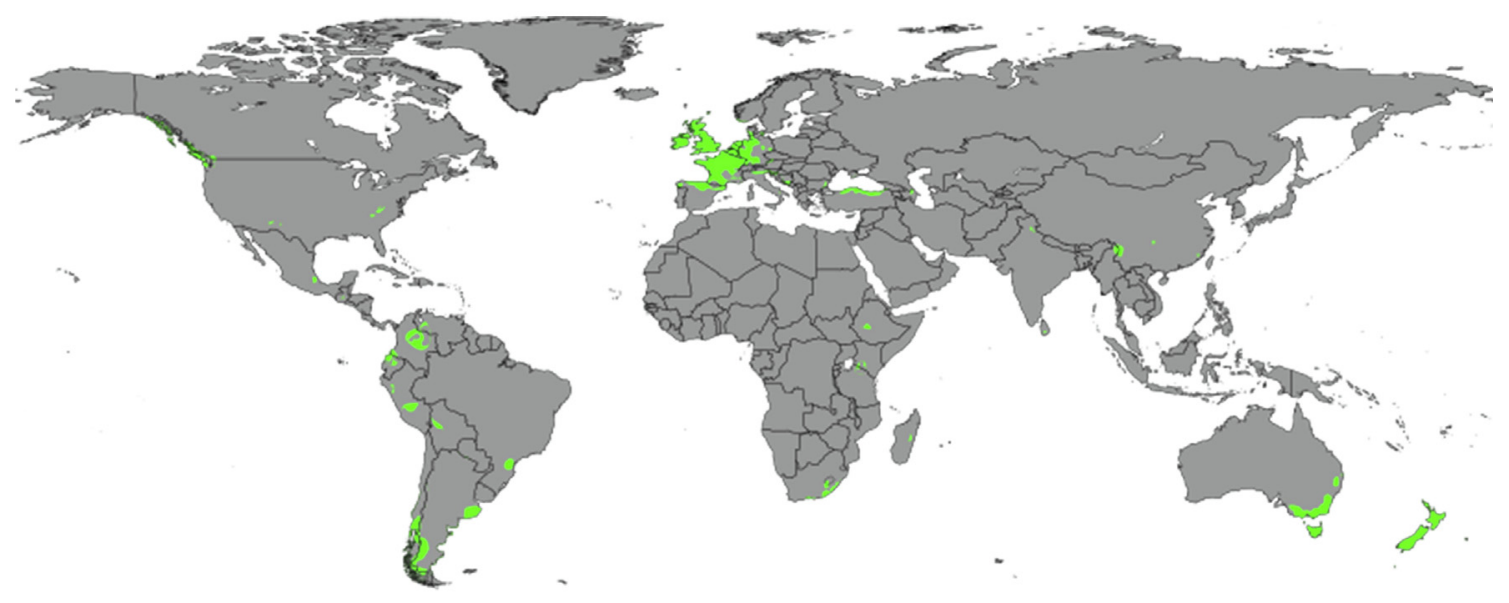

Fig. 2. Worldwide locations with similar climate of Belgium (Temperate oceanic and warm-summer humid continental climates). 
energy consumption of high performance schools and how they can better monitor and control it. The study results reports a significant change of the nature of energy needs of high performance schools towards cooling domination. Therefore, our benchmark can be used in those climates to better compare and verify the energy savings. The aim is to evaluate the market uptake of nZES and provide real performance reference data that can be beneficial for policy and investment managers, clients, architects, engineering firms and contractors.

\section{Methodology}

The research methodology is based on creating representative reference models for nearly-zero energy primary and secondary schools in Belgium. As shown in Fig. 3, the methodology implemented in this paper followed a mixed approach involving empirical monitoring and modeling techniques. The literature review and field visits of recently built schools allowed creating a database of nearly-Zero Energy Schools (nZES). The analyses allowed selecting two representative reference schools and determining their energy consumption and characterize their building performance systems and occupant's behavior. A full energy audit and a three years energy monitoring allowed generating high quality data. This data was then analyzed and used to create two building performance models. The model was calibrated and validated based on the monitored data. The methodology followed in this research is similar to other recent international energy modeling and benchmarking studies [40]. The methodology is similar to the approach of Vasconcelos (2015) [42] who defined a reference building for Portugal and Pagliano (2016) who developed a reference model for child care centers in Italy [43]. The following sections describe in detail the steps undertaken in this research.

\subsection{Literature review}

A literature review was conducted including recent international publications that aimed to develop energy performance benchmarks for school buildings. The publications included scientific manuscript that focus on building energy ratings in European schools. The initial Scopus and Web of Science research resulted in more than 40 publications that are relevant to school's energy efficiency benchmarking. Then, the research scope and focus were narrowed to Passive House schools and nZES resulting in 12 reviewed papers. The publication information was used to contextualize the research in the introduction and discussion section.

This was followed by a local literature review, in the Belgian context. In Belgium, schools can be categorized under three groups:

- Schools owned by the communities (Flemish and French speaking);

- Subsidized public schools (subsidies by provinces and municipalities);

- Subsidized free schools (mainly organized by an organization affiliated to the Catholic Church).

The latter is the largest group, both in number of schools and in number of pupils. The review involved collecting data on energy efficiency from governmental [44] and non-governmental documents [45] (reports [46], magazines [47], television programs, etc.), from formal interviews and pilot studies [48]. The results of the literature review are presented in Section 1.

\subsection{Creation of a data base for nearly Zero energy schools in Belgium}

The current study follows a cross-sectional study design where information was collected from literature and using a survey. An initial database with forty-eight nZES was created to cover the three geographic regions of Belgium (Brussels, Flanders and Wallonia). The database included schools that are built after 2013 and comply or exceed the requirements of the Belgian Passive House Standard (PHS) $[49,50]$. The Belgian nearly Zero Energy Building concept has different technical requirements compared to the German concept [51]. The PHS requires a highly insulated and airtight envelope (an air permeability of less than of $0,6 \mathrm{vol} / \mathrm{h}$ at $50 \mathrm{~Pa}$ ) [52] with a net heating energy demand and net cooling energy demand $\leq 15 \mathrm{kWh} / \mathrm{m}^{2}$ year [44]. The energy demand for heating and cooling should be calculated using a quasi-steady state calculation method, which is the Passive House Planning Package (PHPP) 2007 [53]. The school should include mechanical ventilation with heat recovery (MVHR) [54]. While a zone is considered overheated when 5 percent of its occupied period, exceeds $25{ }^{\circ} \mathrm{C}$ [55] (indoor temperature [15]). The selection criteria involved schools with onsite energy generation system including solar electric and thermal systems and heat pumps. According to the Belgian definition of Passive House, a heat pump is considered as source of renewable energy [56].

The initially screened schools included kindergarten (3-6 year) or pre-primary, primary (6-12 year) and secondary (12-18) schools. The school bidding system or schools delivery process across most of the European member states is based on this classification [57]. The database included several details on each school such as the location, construction age, occupancy density, measured energy heating and cooling, energy use intensity, energy performance certificate details, measured envelope airtightness, compactness of geometry and construction cost. In this stage, the database was compiled, and missing data was completed through field visits and phone or email communication, for standardization. The data collection and analysis were done in line with the European Union General Data Protection Regulation (GDPR) [58]. A final list and complete list of thirty schools was created with a focus on energy efficiency and cost for nZESs for the period from 2015 to 2018. The analysis of the collected data involved finding a correlation between the schools' performances and construction costs in relation to the building performance characteristics.

\subsection{Selection of the representative reference schools}

According to literature, there are three main approaches to create reference models [16]. The first and the most common approach is to create theoretical reference models based on statistical data of the energy performance or thermal comfort of similar building typologies and functions in similar climates. In this approach, a typical meteorological weather file can be used. The second approach is to create a reference model based on one specific and monitored building. This approach is called real reference models. In this approach, a specific weather file needs to be created representing the year the monitoring took place. The third approach is called ideal reference models and seeks to create a reference model based on experts' estimation of input parameters. The

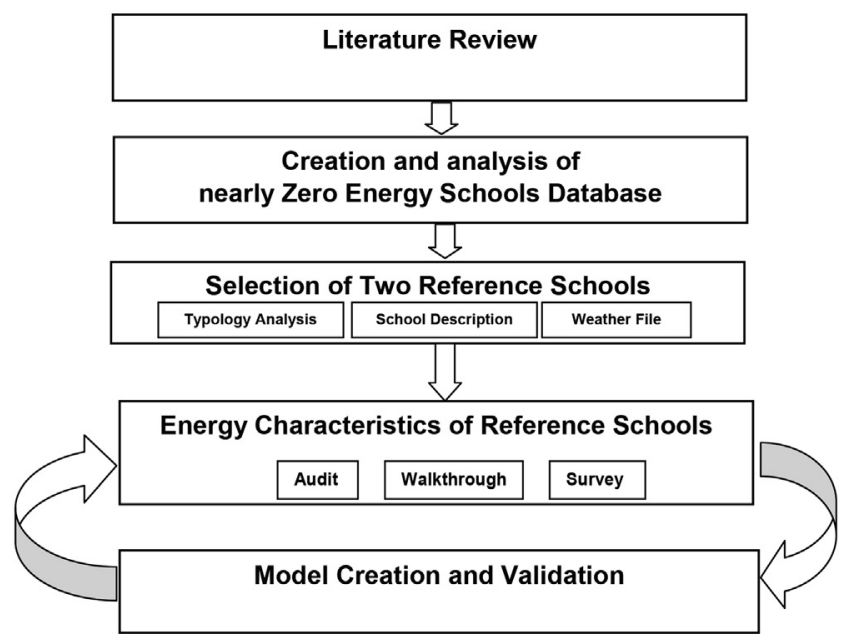

Fig. 3. Conceptual framework for the study methodology. 
ideal building model, defined based on experts' inquiries and assumptions. In this approach, a typical meteorological weather file can be used. Based on the source and type of collected data used modelers can select the type of reference models.

For this study, the first modeling approach (theoretical reference models) was selected because the collected data for the thirty nZESs is representative and abundant. Out of forty-eight nZESs schools a standardized database of thirty schools was created. The sample size was narrowed down in relation to the data accuracy and completion. The database represents the school construction technology commonly applied between 2013 and 2019, in the three regions of Belgium. The common building characteristics and performance patterns could be identified, and cross discipline analysis was possible. In this sense, this study followed the same approach found in already several recent international studied such as the work of Hernandez in the UK [24], Santamouris in Greece [32], Attia in Egypt [40], Beusker in Germany [59] and Gil-Baez in Spain [60].

A typology analysis took place for the thirty schools to select two representative building configurations. Most investigated schools were in urban areas. Plans and forms of thirty school configurations were described and analyzed. Brussels typical meteorological year was selected to perform the simulations. A TMY3 derived from 1991 to 2005 period was used (BEL_Brussels.064510_IWEC) [61]. Belgium is a relatively small country that covers an area of $30,688 \mathrm{~km}^{2}$. The country falls almost completely within Köppen-Geiger classification (Cfb) of temperature oceanic climate with no dry season and warm summer [62]. A part of the east side falls in the (Dfb) cold climate, but no school was in this part. Belgium is heating dominated with an average of 2941 Heating Degree Days (HDD) and 90 Cooling Degree Days (CDD), between 2014 and 2019 (base temperature $15{ }^{\circ} \mathrm{C}$ in the HDD calculation and 24 in CDD calculation) [41]. Overall, the climate in Belgium is mild-cold and humid with significant amount of rainfall during the year. Needless to say, we acknowledge that Köppen-Geiger climate classification is adapted to vegetation for which the rain is most important and may not be best adapted to energy use in buildings. However, it is the most popular and universally used classification method in association with building energy use.

\subsection{Energy characteristics of representative schools}

Two types of energy audit were conducted for the selected school buildings [63]. An analysis of energy consumption (electricity and natural gas) and a walkthrough survey were conducted during May 2018. The energy consumption analysis was done for the occupancy period of 2015-2018 based on monthly consumption data. This step allowed understanding the building performance and identifying the pattern of use, peak demand and seasonal climate impact. The second type of audit was based on walkthrough visits to identify and characterize the energy systems (MVHR, air and water heating systems, heating, ventilation and air conditioning system (HVAC), renewable energy systems, lighting, plug loads and pumps). This was followed by the characterization of the envelope aiming to identify the construction composition, air tightness, window types and solar protection.

After conducting both audits a smart phone-based survey was used to identify the occupancy density and profiles in classrooms based on a seasonal, monthly, weekly and daily level. The survey addresses school teachers and students. The survey sampling was seeking to create indicative information on occupancy and a statically representative characterization. The sampling design consists of a random sample. A free and open-source application was used to collect the data and upload it on a cloud. Once a repetition of the answers pattern was found the request of occupancy information input was stopped. 31 respondents completed the questionnaires in May 2018. The collected data was compiled and analyzed to reflect the energy performance of representative and realistic classroom operation situations when the mechanical ventilation, space heating and space cooling are turned on.
It was very important to identify the building automation systems programing functions, control strategies and sensors parameters. Unfortunately, the data on the renewable energy production was incomplete; therefore, it was not included in the results. To facilitate the understanding of the results of the buildings energy characterization, the results were grouped under four major topics, as described below:

\subsubsection{Occupancy density and profiles}

Data was uploaded into a geo-database that is used to store georeferenced information, which is then used to analyze occupancy information for the classrooms. Data from all surveyed, quantitative and qualitative sources was analyzed holistically to ensure data integration across all sectors. The annual occupancy schedule has been set based on the Flemish and Walloon 2018-2019 annual teaching schedule because most of the case studies were in this region. The holidays have been subtracted from the occupancy schedule.

\subsubsection{HVAC systems and comfort set points}

A special section in the energy audit involved characterizing the HVAC systems and energy source. Description of energy-using systems and components included fan, pump, air handling unit, heat recovery unit, etc. The Domestic How Water use (DHW) and consumption was identified from water meters and the delivered water temperatures were measured. The air flow rate of the MVHR system was measured during different moments of the day to estimate the mechanical ventilation schedule. Also, the Building Management Systems (BMS) was checked and the required data points for comfort control and management built and connected to field devices were reviewed. The programming and set point conditions for air conditioning and boilers were identified.

\subsubsection{Lighting load intensity}

Lighting of common areas (fire stairs, car parks, corridors, foyers) and classrooms was reviewed and occupancy control was identified. The luminaire type has been described, and it has been supposed that all the lighting equipment in the school were recessed. According to the Lighting Handbook the radiant fraction emitted is equal to 0.37 and the visible fraction to 0.18 [64].

\subsubsection{Plug load intensity and schedules}

An inventory of electrical appliances took place to determine the plug load intensities and their operation schedules. The average class electrical appliances presence was determined based on the field survey and walkthrough audit. The unit capacity of the continuously plugged appliances and standby power appliances and the average running hours of each appliance were determined with reference to the collected survey data and appliance catalogues. To facilitate and unify the communication of plug loads for the estimated model, all appliance powers were summarized under one unit of power density.

\subsection{Development of the benchmark models}

Two representative simulation models were made based on the previously described selection process and building characterization. The validity of the estimate has been further checked against the public statistics and verified through a model calibration and utility bill comparison.

The simulations have been performed through the dynamic energy modeling software tool EnergyPlus (Version 8.2.0) [65]. Calibration was done for evaluating the goodness of-fit of the school buildings energy models according to ASHRAE Guideline 14 [66]. The guideline introduces three basic methods to estimate energy use and savings that result from the efficiency measures: the whole building approach, the retrofit isolation approach and the whole building calibrated simulation approach (calibrated simulation). The latter approach was selected for this study. The ASHRAE Guideline 14 uses two indices to evaluate the 


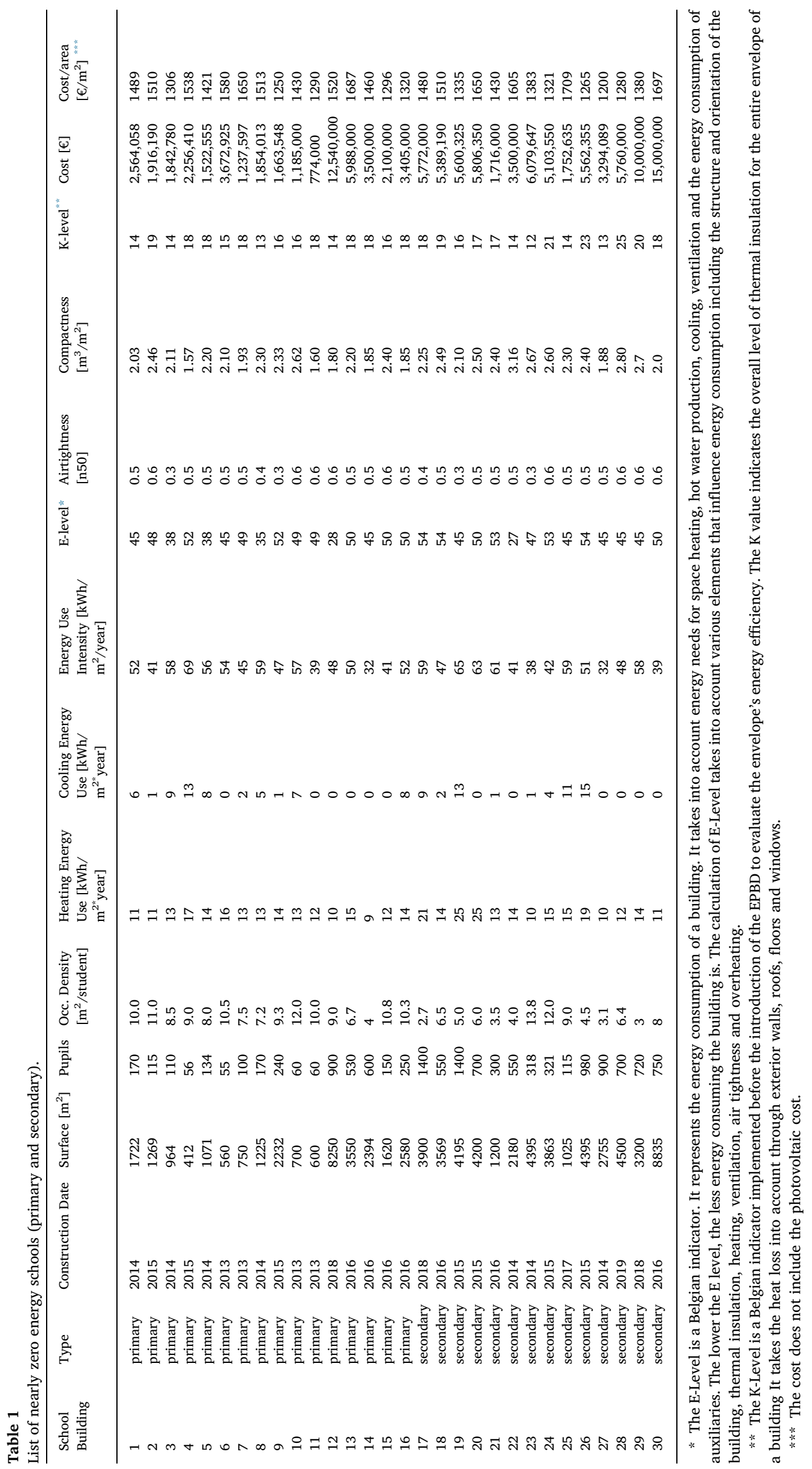


goodness-of-fit of the building energy model. The Mean bias error, $\mathrm{MBE}$, and the Coefficient of variation of the Root mean square error, CV (RMSE). MBE is a non-dimensional measure of the overall bias error between the measured and simulated data in a known time resolution, and it is usually expressed as a percentage:

$M B E=\frac{\sum_{i=1}^{N_{p}}\left(m_{i}-S_{i}\right)}{\sum_{i=1}^{N_{p}} m_{i}}[\%]$

where $m_{i}(i=1,2, \ldots, N p)$ are the measured data, $s_{i}(i=1,2, \ldots, N p)$ are the simulated data at time interval $\mathrm{i}$ and $\mathrm{Np}$ is the total number of the data values.

CV(RMSE) represents how well the simulation model describes the variability in the measured data. It is defined as:

$C V(R M S E)=\frac{1}{m} \sqrt{\frac{\sum_{i=1}^{N_{p}}\left(m_{i}-S_{i}\right)^{2}}{N_{p}}}[\%]$

where besides the quantities already introduced in Eq. (1), $\mathrm{m}$ is the average of the measured data values. The evaluation of the accuracy of a building energy simulation model is made according to the model's conformity with the recommended criteria for MBE and CV(RMSE).

According to the ASHRAE Guideline 14, the simulation model is considered calibrated if it has MBE that is not larger than $5 \%$, and CV (RMSE) that is not larger than $15 \%$, when the monthly data are used for the calibration.

In order to get a reliable building energy model, and to increase the accuracy of the estimation of the building's performance, the models of the schools underwent two subsequent calibrations. The building model was first calibrated on the basis of the building's measured monthly gas consumption then it was refined in free running with a second calibration with respect to monitored hourly indoor air temperatures [43].

In order to identify the independent variables that, at the same time, influence the energy and thermal performances of the building and that are mostly affected by uncertainty, we referred to Hopfe [67]. However, in the present case study of calibration the class sizes are fixed and are not considered as a design variable. The type of windows, the power density of the electric equipment and electric lighting have been precisely quantified with surveys and an energy audit. Hence, they are not sources of significant uncertainty [68], the calibration process focused on testing independent variables that describe airtightness and the occupant density and schedule and the global seasonal efficiency of the heating system.

\section{Results}

After presenting the results of our nearly zero energy schools inventory we describe in detail the two selected reference schools, their energy characteristics and the validation results of the simulation models.

\subsection{Database for nearly zero energy schools}

Table 1 lists thirty selected projects that complied with the Belgian Passive House Standard requirements. The table lists the most important energy performance indicators including occupant density, heating and cooling energy use, energy use intensity and cost. All schools had a conductivity of the envelope (walls, roofs, and ground) equivalent or lower than $0.15 \mathrm{~W} / \mathrm{m}^{2} \mathrm{~K}$ and an air permeability of less than of $0,6 \mathrm{vol} / \mathrm{h}$ at $50 \mathrm{~Pa}$. The energy performance data represents the yearly average values collection between 2015 and 2018 .

\subsubsection{Energy use intensity}

As the survey addressed the billing history of the sample groups, we found average energy use of a typical nZES for heating is $14 \mathrm{kWh} / \mathrm{m}^{2}$ / year, for cooling is $4 \mathrm{kWh} / \mathrm{m}^{2} /$ year and the total energy use intensity is $50 \mathrm{kWh} / \mathrm{m}^{2} /$ year between 2015 and 2018. As shown in Fig. 4, the schools are heating dominated. The cooling energy use was significant. The audit revealed that schools without cooling energy use had no cooling system or had their cooling systems switched off. Based on Fig. 4 we could conclude that several schools had overheating problems. Regarding the type of energy, the major energy use is electric represented by the blue and yellow color (see legend: cooling energy use and electricity use). Electricity forms almost two-third of the total energy use. This reasons for the high electricity use is mainly due to the mechanical ventilation and plug loads.

\subsubsection{Cost}

As shown in Fig. 5, the average cost for the thirty investigated project was 1450 euros per square meter. We could not find a correlation between the energy use intensity and cost. The lowest project cost was 1250 euros $/ \mathrm{m}^{2}$ and the highest was 1709 euros $/ \mathrm{m}^{2}$. The results confirm that the indicated costs per square meter are lower than the average schools constructed in the same period, which is around 1500 euros $/ \mathrm{m}^{2}$ [69].

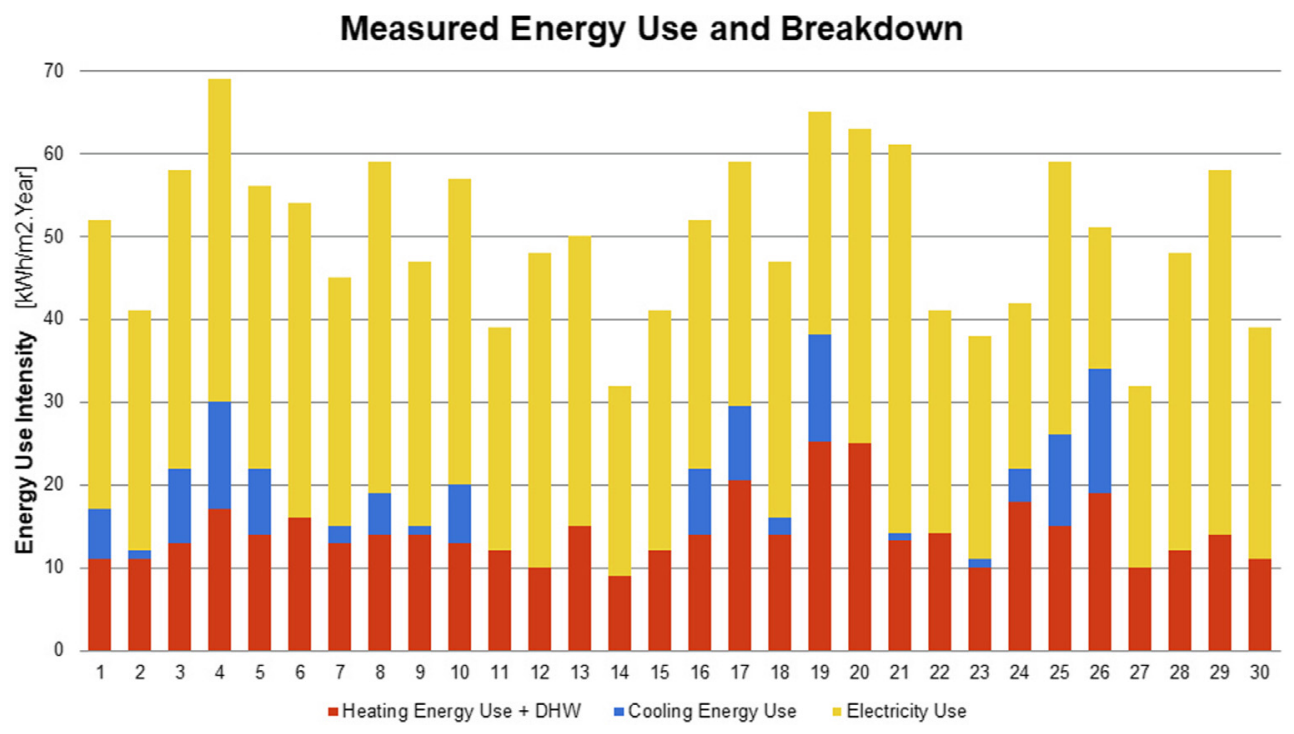

Fig. 4. Measured energy use and breakdown. 


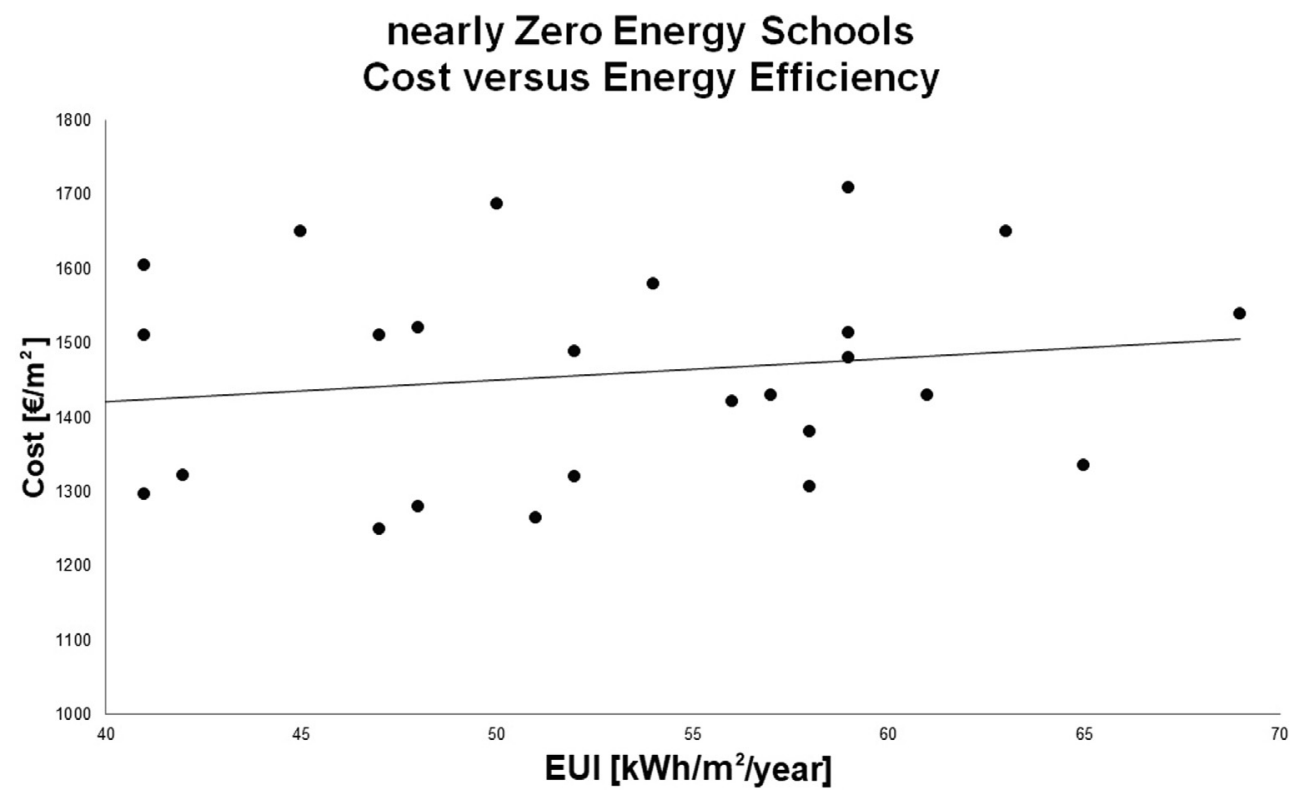

Fig. 5. School construction cost versus energy intensity.

\subsection{Selected reference schools}

Plans and forms of thirty school configurations were analyzed. A replication of the rectangular classroom shape was found across all investigated plans. No specific layout orientation was found dominant or commonly used. Most primary school plans had a compact mass with a two floor and double loaded corridor setting. However, most secondary school plans were less compact. Classes were aligned around double loaded L-shaped or H-shaped corridors with an average of 4 floors.

From the data collected two groups of schools were identified namely primary schools and secondary schools' typologies. Both typologies had to be distinguished due to the disparity regarding use, floor layout, building configuration, occupancy density and energy performance. Primary schools host pupils aged 6-12 years old and are most of the time low-raised. Secondary schools host pupils aged 12-18 and are most of the time more compact and middle-raised. As shown in -8 , two common school typologies were identified and referred to as Typology 1 and 2. For this study, both typologies were selected and identified as representative nZES buildings.

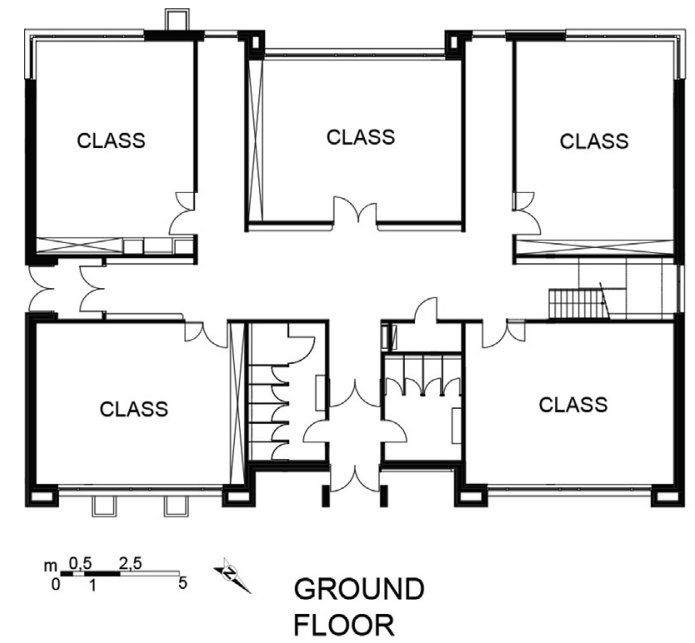

\subsubsection{School buildings description}

The two school types in Figs. 6 and 7 were found to be representative models for schools in the three regions. Both selected typologies were positioned on flat terrain, without surrounding trees or other obstructions that can cast shade on the building mass. The basic building construction is reinforced-concrete post and column with $0.65 \mathrm{~m}$ concrete hollow blocks walls with $30 \mathrm{~cm}$ rigid polystyrene panels insulation. Windows are triple-glazed, coated and transparent of a conductivity of $0.8 \mathrm{~W} / \mathrm{m}^{2} \mathrm{~K}$ and SHGC as low as 0.5 . The total amount of glass in North and South facades is estimated to be between $25 \%$ and $45 \%$ of total wall area. There is no solar protection for the facades and most windows have an internal blind. Next, the average occupancy density for both selected typologies was calculated based on the average area and number of students per class room for all investigated schools. Table 2 presents the values of average classroom density values for nZES primary and secondary schools in Belgium.

To address the different orientation of the surveyed schools, the benchmark models performance was generated by simulating the building with its actual orientation and again after rotating the entire building 90,180 , and $270^{\circ}$, then averaging the results. This is a bestpractice recommended by ASHRAE Standard 90.1 Appendix G [70].

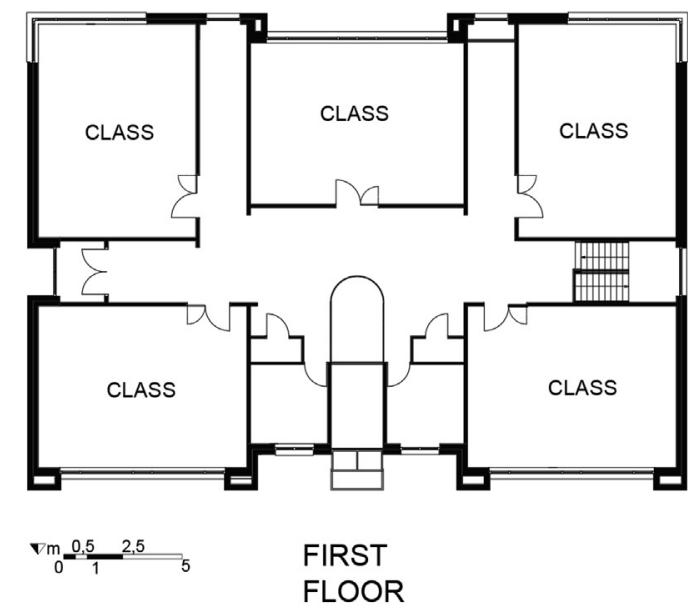

Fig. 6. Floor plans of the primary school. 

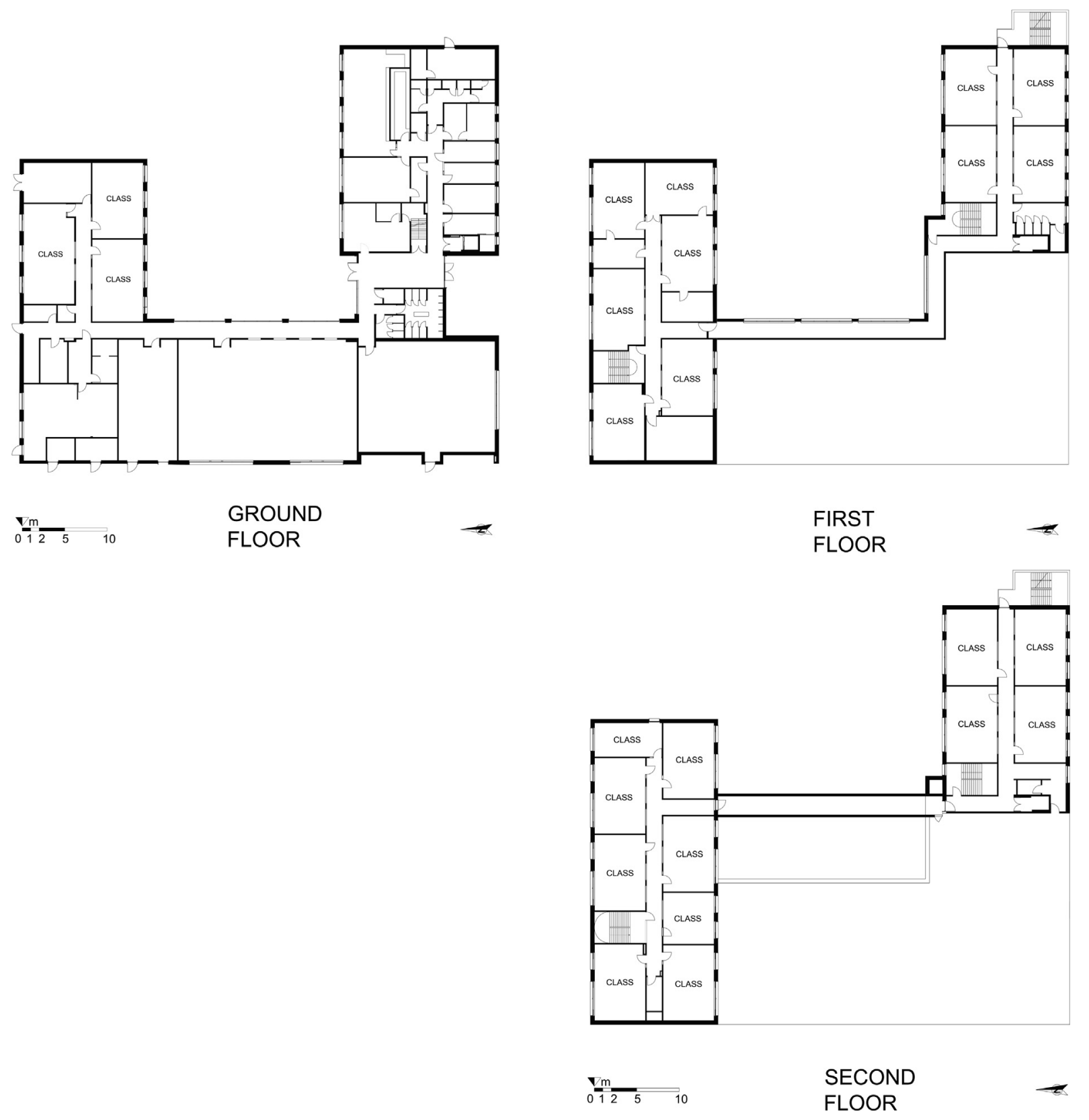

Fig. 7. Floor plans of the secondary school.

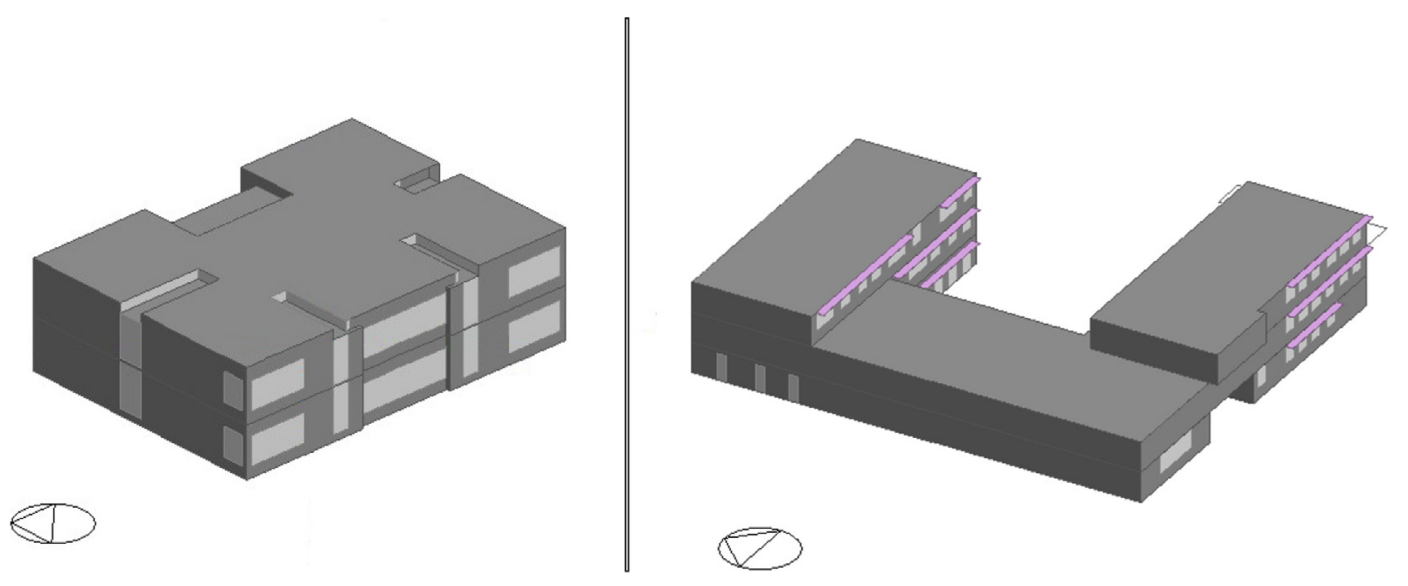

Fig. 8. Primary school and secondary school model in 3D view. 
Table 2

Classroom average area and occupancy density in primary and secondary schools.

\begin{tabular}{lll}
\hline & Primary school & Secondary school \\
\hline Number of classes & 10 & 20 \\
Average class area $\left[\mathrm{m}^{2}\right]$ & 60.4 & 50.8 \\
Occupancy density (Bruto) $\left[\mathrm{m}^{2} /\right.$ student $]$ & 7.2 & 12 \\
Occupancy density (Netto) $\left[\mathrm{m}^{2} /\right.$ student $]$ & 2.5 & 2.8 \\
\hline
\end{tabular}

Table 3

Building typologies description.

\begin{tabular}{lll}
\hline Building description & Primary school & Secondary school \\
\hline Shape & rectangle & U-shape \\
Number of floors & 2 & 3 \\
Volume & $3125 \mathrm{~m}^{3}$ & $15446 \mathrm{~m}^{3}$ \\
External wall area & $866 \mathrm{~m}^{2}$ & $2705 \mathrm{~m}^{2}$ \\
Roof area & $541 \mathrm{~m}^{2}$ & $1841 \mathrm{~m}^{2}$ \\
Floor area & $1225 \mathrm{~m}^{2}$ & $3863 \mathrm{~m}^{2}$ \\
Windows area & $168 \mathrm{~m}^{2}$ & $536 \mathrm{~m}^{2}$ \\
Glazing $U$-Value & 0.8 triple glazing $^{2}$ & $U=0.8$ triple glazing \\
Exterior wall $U$-Value & 0.20 & filled with argon \\
Wall surface absorptance & 0.7 & $U=0.18$ \\
Roof $U$-value $\left(\mathrm{W} / \mathrm{m}^{2} \mathrm{~K}\right)$ & 0.10 & 0.7 \\
Ground $\mathrm{U}$ value $\left(\mathrm{W} / \mathrm{m}^{2} \mathrm{~K}\right)$ & 0.11 & $U=12$ \\
Floor $U$-value $\left(\mathrm{W} / \mathrm{m}^{2} \mathrm{~K}\right)$ & 0.287 & $U=0.11$ \\
\end{tabular}

Table 3, lists the general description of the sample building and some properties for the construction materials used. The full model characteristics description can be found in the results Section 3.3.

\subsection{Energy characterization of reference schools}

The energy characteristics of the two reference schools simulation models are described in this section.

\subsubsection{Energy use intensity}

As the audit addressed the two selected reference schools, we found average energy use intensity for the reference primary school $59 \mathrm{kWh} /$ $\mathrm{m}^{2} /$ year. For the reference secondary school the average energy use intensity is $42 \mathrm{kWh} / \mathrm{m}^{2} /$ year. Table 4 illustrates the average and variance values. According to the Table 4, the secondary schools sample is more widely spread than the sample of primary schools.

\subsubsection{Occupancy density and schedules}

Tables 5 and 6 summarize the holidays and occupation periods use for both schools. Based on available data and our survey, we defined the occupancy period from 7:00 to 18:00 in weekdays while in the weekend the building is considered empty. Results show that the occupation time of a primary or secondary school building is from 08:30 to 16:30. This assumption was made for pupils' occupancy schedules. School employees' presence was included in the models during the earlier time slots and later in the afternoon, for office work (teachers, director) or for cleaning (other employees). An absenteeism of 5\% is taken into account with an operational schedule of 190 academic days.

As shown in Fig. 9, in the opening time of school, only a $10 \%$ of the total people are present at the school, i.e. those who are in charge of the
Table 5

Annual occupancy schedule.

\begin{tabular}{llll}
\hline Season & Weekdays & Saturday & Sunday \\
\hline Season 1 (Feb-Jun) & $7: 00-18: 00$ & - & - \\
Summer holiday (Jul-Aug) & - & - & - \\
Season 2 (Sep-Jan) & $7: 00-18: 00$ & - & - \\
\hline
\end{tabular}

Table 6

The holidays in the teaching school year (2018-2019) in Belgium.

\begin{tabular}{llll}
\hline School holiday & Start date & End date & Week \\
\hline Christmas holiday & $24-12-2018$ & $6 / 1 / 2019$ & $52-01$ \\
Spring break & $4 / 3 / 2019$ & $10 / 3 / 2019$ & 10 \\
Easter holiday & $8 / 4 / 2019$ & $22-04-2019$ & $15-17$ \\
Summer holiday & $1 / 7 / 2019$ & $31-08-2019$ & $27-35$ \\
Autumn break & $28-10-2019$ & $3 / 11 / 2019$ & 44 \\
\hline
\end{tabular}

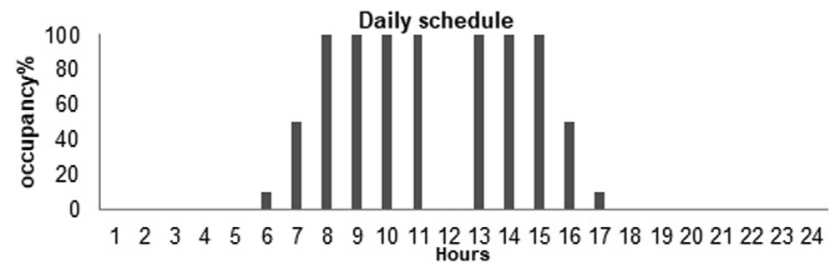

Fig. 9. Occupation schedule for the two school buildings.

preparation of classrooms, toilets and the other services. Then, around 7:30-8:00, more people start coming, those are teachers, employees or students that arrive earlier from the actual beginning of the lessons. The amount of occupants grows until reaching the maximum around 08:30, which is when all the pupils are in their classroom having lessons. This situation stays steady until 16:30, that's when the classes are dismissed. From 16:00 to 18:00 there is a gradual occupancy's decrease. Classed are ended and teachers and other school staff gradually leave the school. Needless to say, a lunch break is assumed daily between 12:00 and 13:00. Both schools are completely empty after 18:00. In primary schools, pupils eat together their home-prepared sandwiches in a common space. In secondary schools, pupils leave the school for lunch.

\subsubsection{Internal load intensities (plug load intensity and schedules)}

The clothing insulation and metabolic heat production were estimated based on NBN-EN 15251 [71] and ter Mors. (2011) [72]. The occupant internal heat gains were estimated to be $80 \mathrm{~W} /$ pers and the equipment heat gains were estimated to be $1 \mathrm{~W} / \mathrm{m}^{2}$. All classrooms were modeled without computers with a plug load density of $5 \mathrm{~W} / \mathrm{m}^{2}$. We assumed that only teachers might have access to PCs, in the classroom, and therefore, it was considered as negligible.

\subsubsection{HVAC systems and comfort set points}

In both reference schools, mechanical ventilation with heat recovery is installed. The HVAC system is couple to an air handling unit located in the technical rooms with a Constant Air Volume (CAV) system to provide the minimum amount of fresh air per person of $20 \mathrm{~m}^{3} / \mathrm{h}$, according to the school day occupancy schedule. This ventilation rate was based on the average Flemish and Walloon EPBD

Table 4

Average heating, cooling and energy use intensity.

\begin{tabular}{|c|c|c|c|c|c|c|}
\hline School Type & $\begin{array}{l}\text { Average Heating Energy Demand [kWh/ } \\
\mathrm{m}^{2} \text { year] }\end{array}$ & Variance & $\begin{array}{l}\text { Average Cooling Energy Demand [kWh/ } \\
\mathrm{m}^{2} \text { year] }\end{array}$ & Variance & $\begin{array}{l}\text { Average Energy Use Intensity }\left[\mathrm{kWh} / \mathrm{m}^{2}\right. \\
\text { year] }\end{array}$ & Variance \\
\hline Primary & 14 & 4.25 & 5 & 16.8 & 59 & 78.8 \\
\hline Secondary & 18 & 23.7 & 4 & 28.1 & 42 & 106.3 \\
\hline
\end{tabular}


requirements in relation to the activity level and the age of the occupant (NBN EN 13799) [73]. The reference case has been modeled using as HVAC template with a CAV. This CAV system consists of a supply air stream of variable temperature and a modulation of the amount of the air that serves a space. The air handling units are controlled by a user profile schedule. An air-to-air heat exchanger is bypassed when the indoor operative temperature is lower than the indoor air temperature. Each class room is pre-ventilated during $1 \mathrm{~h}$ before the start of the school. The minimum supply air temperature is $16{ }^{\circ} \mathrm{C}$. The heat recovery system preheats the air with an efficiency of $75 \%$.

The gas-fired boiler was modeled with an average a Coefficient of Performance (COP) of 0.9 coupled to the hot water loop for heating and sanitary hot water. During the heating period, the rooms' set point temperature is $20{ }^{\circ} \mathrm{C}$ (minimum $16{ }^{\circ} \mathrm{C}$ ). Both selected schools had a mechanical cooling system and were modeled with a mechanical cooling system (Variable Refrigerant Flow (VRF) system).

\subsubsection{Lighting load intensity}

Lighting systems had a power consumption of $6 \mathrm{~W} / \mathrm{m}^{2}$ and was programmed in EnergyPlus as $2 \mathrm{~W} / \mathrm{m}^{2}$ per 100 Lux of light level. Then, we used a $300 \mathrm{~lx}$ threshold to reach the $6 \mathrm{~W} / \mathrm{m}^{2}$. A daylight control system is coupled to a centrally positioned daylight sensor. The required illuminance of each classroom is specified in NBN EN 12464-1 [74].

\subsubsection{Plug load intensity and schedules}

3.3.6.1. Simulation model and validation. Two representative simulation models were built taking into account the previously described envelope, occupancy and energy systems and characteristics. As shown in Table 7, the major model input parameter values are listed. The validity of the estimate has been further checked against literature [12], public reports including AGION 2015 [44] and 2019 reports [10], the Flemish Ministry of Education [47] and through model calibration [66] and monthly and annual energy use bills [75].

\subsubsection{Numerical model calibration}

The MBE and CV(RMSE) of monthly energy use for four consecutive years are calculated for both school models and reported in Table 8. The obtained values of both MBE and CV(RMSE) are within acceptable limits of \pm 5 and \pm 15 , respectively [76]. The negative signs indicated that the model over predicts the energy consumption on average.

Figs. 10 and 12 show the estimated gas use simulated in both models and the real gas use of both actual buildings. The model calibration was done over four years and involved several reviews from peer modelers at the Belgian Passive House Standard not-for-profit organization. All the previous load schedules were included in both models. A good agreement was found in the monthly energy use behavior and curve shapes between the simulated data and the survey collected data. The box plot upper and lower extremes represents the lowest and highest measured monthly energy use. The upper and lower quartile of the red box includes $80 \%$ of the monthly measurements.

Figs. 11 and 13 show the estimated electricity use simulated in both models and the real electricity use of both actual buildings. In Fig. 11, the estimated electricity use curve shape is offset towards higher limits than the measured electricity use. In Fig. 13, the estimated electricity use curve shape is offset towards lower limits than the measured electricity use. However, a good agreement was found in the monthly electricity use behavior and curve shapes between the simulated data and the survey collected data. The box plot upper and lower extremes represents the lowest and highest measured monthly electricity use. The upper and lower quartile of the red box includes $80 \%$ of the monthly measurements.

\section{Discussion}

In the following section, we will discuss the major findings of the study and elaborate on its strength and limitation before elaborating on the implications of the study on practice and research.

\subsection{Summary of the main findings}

For this study, we developed and validated two reference models for nearly Zero Energy Schools (nZES) in Belgium. Both models represent primary and secondary schools recently built in Belgium. Our research methodology combines mixed methods of research involving qualitative (e.g., literature review and smart phone base survey) and quantitative empirical and modeling (e.g., walkthrough audits, building performance simulation, calibration) research. In the recent, years Belgium has been busy supporting projects to construct passive and nZES as a wide policy goal to increase energy performance and sustainability of education facilities. Therefore, benchmarking those newly constructed schools serves as a mechanism to evaluate and assess their real energy performance of buildings over time and share learned lessons. Benchmarking allows characterizing them through reference models in

Table 7

Summary of input parameters for both benchmark models after calibration.

\begin{tabular}{|c|c|c|c|}
\hline \multicolumn{2}{|l|}{ Model input measures } & \multirow{2}{*}{$\begin{array}{l}\begin{array}{l}\text { Primary } \\
\text { school }\end{array} \\
\text { N22, S45, } \\
\text { E35, W28 }\end{array}$} & \multirow{2}{*}{$\begin{array}{l}\begin{array}{l}\text { Secondary } \\
\text { school }\end{array} \\
\begin{array}{l}\text { N30, S25, } \\
\text { E15, W,26 }\end{array}\end{array}$} \\
\hline Envelope & $\mathrm{WWR}=(\%)$ & & \\
\hline & Openings $\left[\mathrm{W} / \mathrm{m}^{2} \mathrm{~K}\right]$ & $U=0.78$ & $U=0.78$ \\
\hline & $\begin{array}{l}\text { Shading coefficient for } \\
\text { glass, SC }\end{array}$ & 0.7 & 0.7 \\
\hline & Solar Heat Gain & 0.5 & 0.5 \\
\hline & Coefficient (SHGC) & & \\
\hline & Light transmittance (LT) & 0.66 & 0.66 \\
\hline & LSGR(LT/SHGC) & 1.4 & 1.4 \\
\hline & $\begin{array}{l}\text { Overhangs, projection } \\
\text { factor PF }(E, W, S)\end{array}$ & 0 & 0.83 \\
\hline & SGR (blind/screen) & Blind 0.5 & Blind 0.5 \\
\hline & $\begin{array}{l}\text { Wall U Value }=\left[\mathrm{W} / \mathrm{m}^{2}\right. \\
\mathrm{K}]\end{array}$ & $U=0.107$ & $U=0.107$ \\
\hline & $\begin{array}{l}\text { Wall surface } \\
\text { absorptance, CCF }\end{array}$ & 0.7 & 0.7 \\
\hline & Roof $\left[\mathrm{W} /\left(\mathrm{m}^{2} \mathrm{~K}\right]\right.$ & $U=0.094$ & $U=0.094$ \\
\hline & Air tightness & 0.6 & 0.6 \\
\hline & $\begin{array}{l}\text { Roof surface } \\
\text { absorptance, CCF }\end{array}$ & 0.6 & 0.6 \\
\hline \multirow{11}{*}{$\begin{array}{l}\text { Ventilation and air } \\
\text { conditioning }\end{array}$} & $\mathrm{COP} / \mathrm{EER}$ & 0.85 & 0.85 \\
\hline & $\begin{array}{l}\text { Temperature set point } \\
{\left[{ }^{\circ} \mathrm{C}\right] \text { for heating }}\end{array}$ & 18 & 21 \\
\hline & $\begin{array}{l}\text { Temperature set point } \\
{\left[{ }^{\circ} \mathrm{C}\right] \text { cooling }}\end{array}$ & 25 & 25 \\
\hline & $\begin{array}{l}\text { Mechanical ventilation } \\
\text { system }\end{array}$ & VAV & \\
\hline & $\begin{array}{l}\text { Outside air } 1 / \mathrm{s} \text { per } \\
\text { person) }\end{array}$ & 5.5 & 5.5 \\
\hline & Air changes per hour & 2 & 2 \\
\hline & Heating system & Convective & Convective \\
\hline & Heating fuel & Natural Gas & Natural Gas \\
\hline & $\begin{array}{l}\text { Daily operative hours for } \\
\text { ventilation/heating }\end{array}$ & $\begin{array}{l}\text { Occupancy } \\
\text { schedule }\end{array}$ & $\begin{array}{l}\text { Occupancy } \\
\text { schedule }\end{array}$ \\
\hline & $\begin{array}{l}\text { Relative humidity set } \\
\text { point [\%] - Adaptive }\end{array}$ & $20-70 \%$ & $20-70 \%$ \\
\hline & Radiant fraction & 0.37 & 0.37 \\
\hline \multirow[t]{3}{*}{ Lighting } & Visible fraction & 0.18 & 0.18 \\
\hline & $\begin{array}{l}\text { Installation power } \\
\text { density }\left[\mathrm{W} / \mathrm{m}^{2}\right]\end{array}$ & 6 & 6 \\
\hline & Number of people & 24 & 18 \\
\hline \multirow[t]{3}{*}{ Occupancy } & Average area of the Class & 60 & 51 \\
\hline & Density & 2.5 & 2.8 \\
\hline & Occupancy schedule & See Fig. 7 & See Fig. 7 \\
\hline Total & $\begin{array}{l}\text { Average consumption } \\
{\left[\mathrm{kWh} / \mathrm{m}^{2} / \text { year }\right]}\end{array}$ & 59 & 42 \\
\hline
\end{tabular}


Table 8

MBE and CV(RMSE) of the monthly energy use of both reference school models from 2015 to 2018.

\begin{tabular}{|c|c|c|c|c|c|c|c|c|}
\hline \multirow[b]{2}{*}{ Statistical indices } & \multicolumn{2}{|l|}{2016} & \multicolumn{2}{|l|}{2017} & \multicolumn{2}{|l|}{2018} & \multicolumn{2}{|l|}{ Average } \\
\hline & MBE (\%) & CV(RMSE) (\%) & MBE (\%) & CV(RMSE) (\%) & MBE (\%) & CV(RMSE) (\%) & MBE (\%) & CV(RMSE) (\%) \\
\hline Reference School 1 Monthly Calibration (Natural Gas) & +5 & -14 & -6 & -12 & -2 & -8 & -3 & -11 \\
\hline Reference School 1 Monthly Calibration (Electricity) & 5 & 10 & 3 & 14 & 4 & 12 & 4 & 12 \\
\hline Reference School 2 Monthly Calibration (Natural Gas) & 3 & 14 & 4 & 10 & 4 & 9 & 4 & 11 \\
\hline Reference School 2 Monthly Calibration (Electricity) & 4 & 17 & 5 & 11 & 5 & 11 & 5 & 14 \\
\hline
\end{tabular}

order to enable reliable simulations and future improvement.

To summarize the major benchmarking-based findings, we list the most important and tangible outcomes of our building performance characterization (see Table 7):

- An inventory and database with thirty nZES was created describing the major energy and occupancy performance criteria collected between 2015 and 2018 .

- Two new benchmark models for primary and secondary schools were created in EnergyPlus based on the representative building stock performance of nZES and were calibrated based on the ASHRAE BESTEST requirements [76].

- The average energy use intensity of the primary and secondary nZES is $59 \mathrm{kWh} / \mathrm{m}^{2} /$ year and $42 \mathrm{kWh} / \mathrm{m}^{2} /$ year, respectively. Table 4 illustrates the average values.

- In the temperate climate of Belgium (Köppen Cfb: Marine West Coast Climate), the breakdown of the energy use intensity of thirty nZES schools is 28 percent for heating, 8 percent for cooling and 64 percent for electricity energy use (mechanical ventilation, lighting, plug loads and pumps), based on Table 1 and Fig. 4. The building energy use is dominated by mechanical ventilation.

- The average electricity consumption is mainly a result of mechanical ventilation and the presence of PC's and video projectors.

- The average energy intensity for cooling and heating is higher than $15 \mathrm{kWh} / \mathrm{m}^{2} /$ year in many nZES.

- The average cost for the thirty investigated project was 1450 euros per square meter, as shown in Fig. 5, which is in the range $( \pm 12)$ of conventional construction cost (2015-2018) (see Section 3.2.1).

- Remarkably, the model estimate low heat losses of the envelope due to compactness, insulation and airtightness. The average building envelope air permeability was less than of $0,54 \mathrm{vol} / \mathrm{h}$ at $50 \mathrm{~Pa}$ and the envelope conductivity was below $0.2 \mathrm{~W} / \mathrm{m}^{2} \mathrm{~K}$. Most schools had concrete hollow blocks walls with rigid polystyrene insulation and external brick leaf.

- Most windows were triple-glazed with an average conductivity of $0.8 \mathrm{~W} / \mathrm{m}^{2} \mathrm{~K}$, and g-value of 0.5 . However, more than $73 \%$ of the schools had no external solar protection.

- Surprisingly, more than 40 percent of the investigated schools did not have a cooling system nor had their cooling system switched on. Some of the investigated schools had their mechanical ventilation system switched off due to high electricity bills.

- Nearly Zero Energy Schools needs are cooling and electricity dominated

\subsection{Strength and limitations of the study}

We created two simulation models and validated them with real monthly energy use data for natural gas and electricity for more than three years (2015 and 2018). No previous study, explored this terrain and until this moment there is no single benchmark for nearly Zero Energy Schools that is open-access and validated based on a database of 30 schools with monthly measurements of more than three years. Our work is part of the activities of OCCuPANt project (Impacts Of Climate Change on the indoor environmental and energy PerformAnce of buildiNgs in Belgium during summer) that aims to benchmark the performance of high performance buildings in Belgium. European experts in several organizations including the Buildings Performance Institute Europe (BPIE) explicitly identified the need to create benchmark models that are validated and that can be used to assess energy use, indoor environmental quality and user interaction in high performance buildings [56]. The findings of the past TABULA project [77] and ZEBRA 2020 (nearly Zero-Energy Building Strategy 2020) project efforts confirm the need to create real reference models for new buildings, as well as old buildings [78].

Benchmark models have a great influence on informing the design decision making during design and building energy use and indoor environmental quality during operation [78]. The implications of energy efficiency on building thermal comfort are severe and climate change can jeopardize many efforts to reduce the cooling requirements and cooling systems [79]. Benchmark models provide greater resources for energy modelers and energy simulation experts and allow to bridge the energy performance gap between operational and designed performance [80]. By reviewing the literature in Section 1, we identified a significant interest in renovation of existing schools [13] across different climates of the world [81], however, few studies are concerned with new and high performance schools. Therefore, solid performance

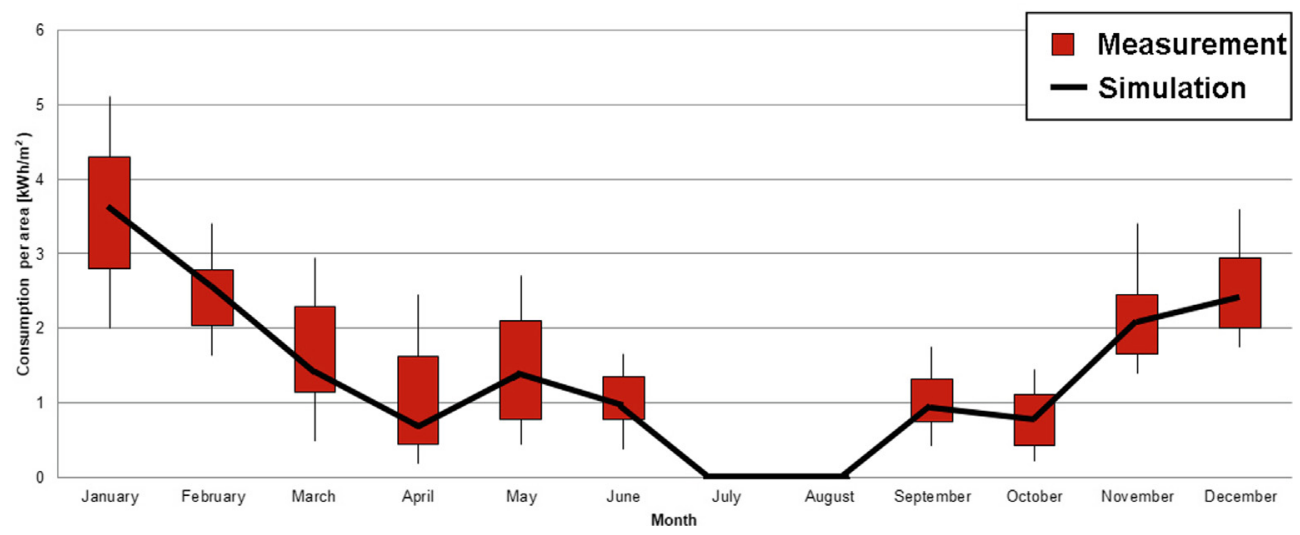

Fig. 10. Surveyed and simulated monthly gas use of the primary school. 


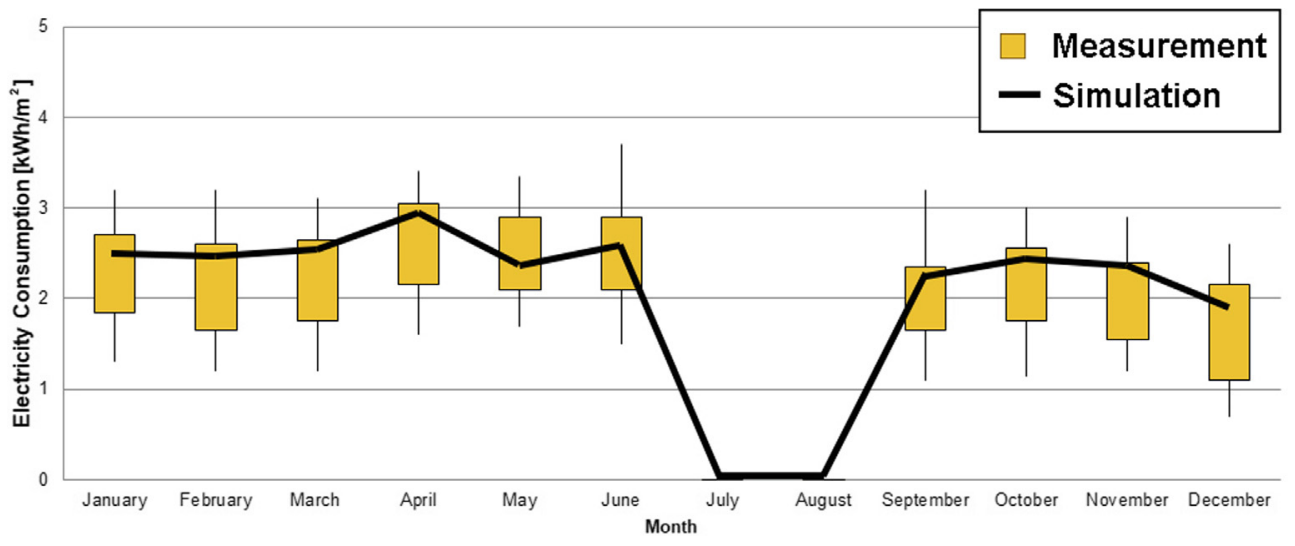

Fig. 11. Surveyed and simulated monthly gas use of the secondary school.

analysis can be performed to estimate the future energy performance of new school buildings and help building operators to identify the performance discrepancies (energy, comfort, cost) during operation [3]. They can also be useful for sale or rental purposes.

Another benefit of our two benchmark models is to inform regulation and the regional EPBD experts. The study succeeded to characterize both reference schools in a prescriptive and performance-based way, which allows a better understanding of the schools energy performance. For instance, Hernandez (2008) showed that benchmark models for Irish primary schools allowed to comparison with representative building stock performance which was a vital step to change the regulation compliance and certification process [24]. In this context, our paper presents one of the few cross-sectional studies where researchers compile a database for a representative building stock performance of nZES during a specific period of four years. The study is not only valuable in Belgium but findings on energy needs and use intensity are useful in countries with temperate and continental climates. Also, we consulted energy modeling experts and scientist to justify several modeling assumptions for our energy models that we consider as a good start. We know that our benchmark models are not perfect but it should be seen as novel contribution that future researcher should build upon and include comfort and air quality data or address in overall the indoor environmental quality.

Needless to say, we only chose to calibrate our model using monthly data for almost four years. We should ideally have tested our models against hourly operative temperature data and investigated the variations in occupancy. We could not have a full access to monitor the operative temperature, humidity, carbon dioxide, occupancy variations or even the solar electric photovoltaic generation for both of our reference buildings, until now. We did our best to push the limits of our database and include thirty cases and get a good representative sample of the nZES building stock performance that can be developed in the future. But we had the advantage to have all building built 2013-2018 with almost the same energy performance requirements.

Another limitation is that we focused mainly on benchmark development and not on characterizing indoor environmental quality and the correlation between the air quality and energy use intensity. Indoor environmental quality in educational buildings is a versatile topic that gained many attention during the last two decades [82]. The topic does not only address the four major IEQ indicators but involves human perception and occupant interaction with the classrooms environment [83]. Therefore, in this study, indoor temperature and air change rates have been assigned standard and estimated values. In fact, we did not want to provide an evaluation of indoor environmental quality of current schools; we rather wanted to create two new benchmark models that can be used easily by professionals and researchers in nZES. The benchmark models succeeded to characterize geometry, envelope, occupancy and HVAC systems in direct relation to thermal and energy performance. Future work, should address indoor environmental quality through post-occupancy evaluations in those schools more thoroughly. More importantly, there is a necessity to define the ventilation rates required in those schools spaces in relation to the energy losses and the overall efficiency of the mechanical ventilation systems, including heat recovery. The findings indicate that most schools' energy use is electric as a effect of IAQ ventilation. Therefore, future work should portray the adverse effect of IAQ ventilation on energy use intensity.

\subsection{Implications for the practice and future research}

In summary, this study presents two novel benchmark models with good validity to be used to assess energy performance of nZES. Future

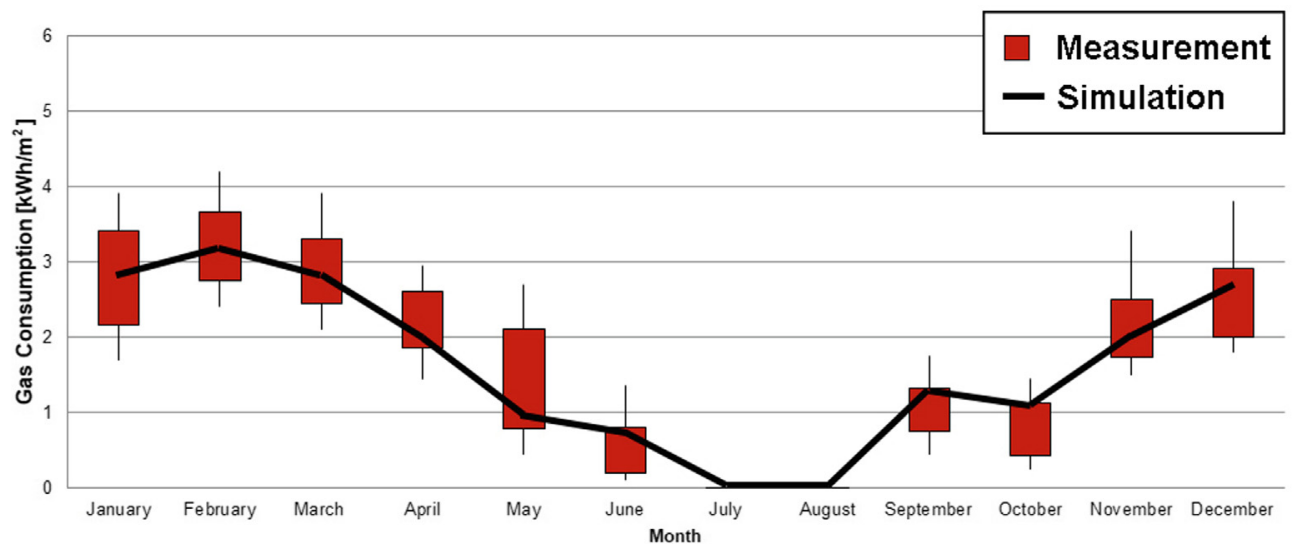

Fig. 12. Surveyed and simulated monthly electricity use of the primary school. 


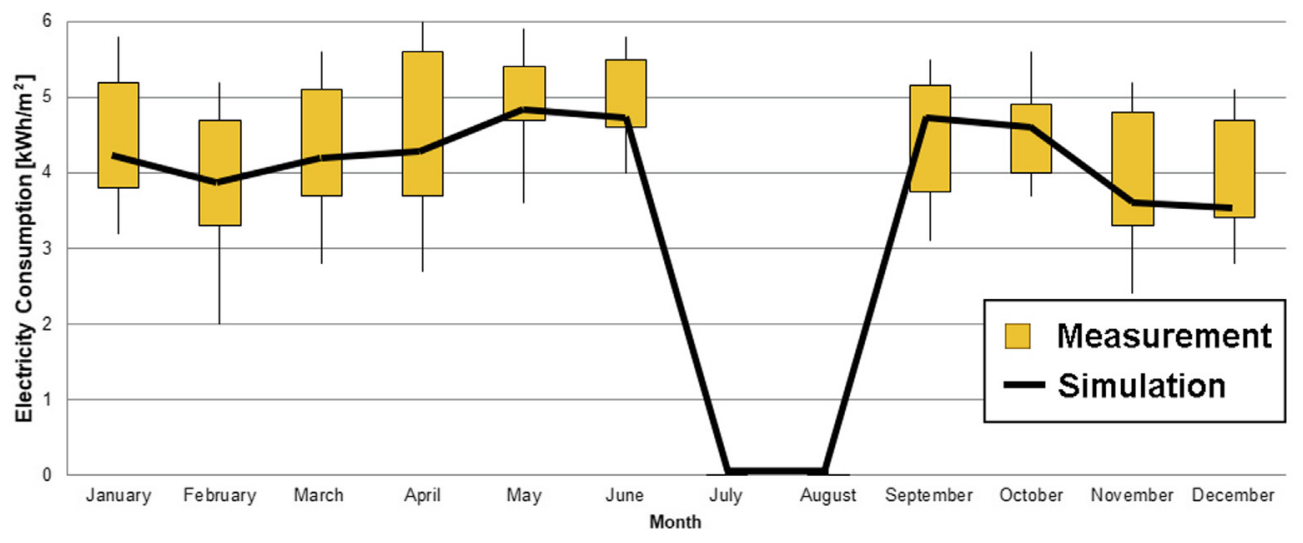

Fig. 13. Surveyed and simulated monthly electricity use of the secondary school.

research should test our building models with the occupant in a wider context and with a large sample of students with respect to indoor environmental quality [84]. More work is also needed to compare our benchmark models results with estimation of the nZEB-tool developed by the PHPP [85]. We expect that the use of multi-zone dynamic simulation models would lead to less discrepancy between the assumed modeling input and real occupancy and operation conditions in relation to ventilation systems and air change rates [86].

The implication of our work on practice can lead to revision of the EPBD and Belgian Passive House Standard requirements (PMP and Pixii). Belgium missed several opportunities to develop its own referential rating systems for green and healthy schools. A good example is CIBSE's TM57 reference for integrated school design [87]. Therefore, very much of lost time and discussions take place when defining green and healthy schools. Also, there are too many fragmented entities that are responsible of schools and education in Belgium (schools owned by the communities, subsidized public schools, and subsidized free schools). As a result, there is a lack of understanding and shared knowledge on best practices of high performance schools design and operation. Our study can contribute to larger initiatives and projects, such as Scholen van Morgen, Scholenbouwen, Gezonde Scholen and Mon Ecole un espace de qualite, by sharing learned lessons and representative performance data for recently construction schools. Comparison can be made during early design stages to assess and evaluate different design assumptions and boundary conditions. As a direct implication of our work, we advise countries with temperate climate in Europe and Worldwide to adopt our benchmark models and refine them accordingly to estimate and evaluate the energy performance of nZES, in their context. A project such as TABULA in the EU or Re-energising Wales in the United Kingdom (UK) should be extended beyond residential buildings, therefore, the EU should create databases of building benchmarks similar to the CBECS in the USA [88].

Through this study, we succeeded to characterize Belgian nZES energy efficiency, which can provide insights for European member states [89]. Surprisingly, the dominance of electricity use in all schools emerged as an important factor that was undermined in our initial model creation. Our research provided a detailed characterization of the energy performance gap in recently construction high performance schools. Future research should, extend the focus on breaking down the electricity use under more items and measure their validity and relevance. We believe that heat gains, lack of solar protection and the air change rates are the most important parameters that influence the energy performance of nZES. Future detailed audit should take place to assess the operation and model assumption of mechanical ventilation systems. Further research and adoption of the same benchmark models would be excellent avenues for further research for further validating and generalizability of the proposed models for nZES design and operation.

\section{Conclusion}

In this study, the energy use intensity and energy use breakdown of thirty nearly Zero Energy Schools (nZES), located in various areas throughout Belgium, is estimated and compared based on a four-year measurement data (2015-2018). Two representative reference models were created and calibrated using EnergyPlus software. Study results indicate that both created reference models have a good validity in assessing the energy performance of nearly Zero Energy Schools built between 2015 and 2018 in Belgium. The models are reliable and consistent and can be used by future building energy modelers and experts. The models were calibrated according to ASHRAE Guideline 14 using two indices to evaluate the goodness-of-fit of the building energy model. The Mean bias error, MBE, and the Coefficient of variation of the Root mean square error, CV(RMSE) were used to proof that both model are accurate and valid.

The dominant energy use of electricity in Belgian nZES is mainly related to the intensive use of mechanical ventilation and electric installations. Most of the investigated school succeeded to decrease the energy needs for heating and cooling. However, thermal comfort, which was not investigated in this study, seems to be problematic. The cooing use was significant in a temperature climate such as Belgium and in schools, which are only occupied $27 \%$ (in average $2360 \mathrm{~h} /$ yearly) of the year. The lack of solar protection for largely glazed facades, the lack of thermal inertia activation due to night cooling blocking (for security reasons) are among the reasons of cooling energy needs increase.

Furthermore, although the contribution of photovoltaic systems is not taken into consideration as the focus was mainly on the building's energy efficiency, this study highlights that most those schools were built with a similar cost per square meter. The small variance is mainly due to the strict budget control that maintained during the project delivery process. In this context, the study provided valuable insights on the cost.

Finally, the study provides several insights on the reference schools building and systems characteristics. The result confirms the presence of a significant energy performance gap between the early design performance assumptions and the real performance. The models can guide school design decisions, operators and school owners about the energy performance and energy use intensity and help them to characterize nearly Zero Energy Schools.

\section{CRediT authorship contribution statement}

Shady Attia: Conceptualization, Supervision, Methodology, Writing - original draft, Validation, Writing - review \& editing. Niloufar Shadmanfar: Investigation, Software, Data curation. Federico Ricci: Investigation, Software, Data curation. 


\section{Declaration of Competing Interest}

The authors declare that they have no known competing financial interests or personal relationships that could have appeared to influence the work reported in this paper.

\section{Acknowledgement}

The authors express their thanks to all survey respondents. This research was partially funded by the Walloon Region under the call 'Actions de Recherche Concertées 2019 (ARC)' and the project OCCuPANt, on the Impacts Of Climate Change on the indoor environmental and energy PerformAnce of buildiNgs in Belgium during summer. The authors would like to gratefully acknowledge the Walloon Region and Liege University for funding. Also, we would like to acknowledge the Sustainable Building Design Lab for the use of monitoring equipment in this research and the valuable support during the experiments and data analysis.

\section{Appendix A. Supplementary material}

Supplementary data to this article can be found online at https:// doi.org/10.1016/j.apenergy.2020.114614.

\section{References}

[1] Recast E. Directive 2010/31/EU of the European parliament and of the council of 19 May 2010 on the energy performance of buildings (recast). Off. J. Eur. Union 2010;18(06):2010.

[2] Parliament E. Directive 2018/844/EU of the European Parliament and of the council of 19 June 2018 on the energy performance of buildings (recast). Off. J. Eur. Commun. 2018;61(156):75-91.

[3] Attia S. Net Zero Energy Buildings (NZEB): concepts, frameworks and roadmap for project analysis and implementation. Butterworth-Heinemann; 2018.

[4] Lanniello E, d'Ambrosio Alfano FR. WS10: The REHVA guidebook on indoor environment and energy efficiency in schools-Part 1. Principles. REHVA J 2010.

[5] EnEffect. IEE PassREg passive house regions with renewable energies. Success guide; Jun. 2013.

[6] AGION. Pilootproject Passiefscholen. https://www.agion.be/pilootprojectpassiefscholen [Online]. Available: https://www.agion.be/pilootprojectpassiefscholen. [accessed: 11-Nov-2019].

[7] Breesch H, Wauman B, Klein R, Versele A. Design of a new nZEB test school building. REHVA J 2016;53:17-20.

[8] FWB. Ecole au standard passif. FWB Infrastructure; 20-Dec-2019. [Online]. Available: http://www.infrastructures.cfwb.be/index.php?id =648 [accessed: 20Dec-2019].

[9] Hutton PC. Zero energy schools-beyond platinum. Educ. Facil. Plan. 2011;45(3):43-6.

[10] AGION. Evaluatie scholen van morgen. Agentschap voor Infrastructuur in het Onderwijs, Brussels; 2019.

[11] Piderit MB, Vivanco F, Attia S. Roadmap for net zero energy schools in Chile. Sustain Built Environ Urban Plan Glob Probl Local Policies 2019:145-51.

[12] Gaitani N, Cases L, Mastrapostoli E, Eliopoulou E. Paving the way to nearly zero energy schools in Mediterranean region-ZEMedS project. Energy Procedia 2015;78:3348-53.

[13] Zeiler W, Boxem G. Net-zero energy building schools. Renew Energy 2013;49:282-6.

[14] De Reys G. Remediëring oververhittingsrisico passiefschool op basis van dynamische simulaties.

[15] Wauman B, Klein R, Breesch H, Van Loon S, Baetens R, Saelens D. Determination of boundary conditions for passive schools: impact on net energy demand for heating and cooling. Workshop/studio, vol. 44. 2010. p. 100.

[16] Corgnati SP, Fabrizio E, Filippi M, Monetti V. Reference buildings for cost optimal analysis: Method of definition and application. Appl Energy 2013;102:983-93.

[17] E. U. Commission. Commission delegated regulation (EU) No 244/2012 of 16 January 2012 supplementing Directive 2010/31. EU Eur. Parliam. Counc. Energy Perform. Build.

[18] Khoshbakht M, Gou Z, Dupre K. Energy use characteristics and benchmarking for higher education buildings. Energy Build 2018;164:61-76.

[19] Pereira LD, Neto L, Bernardo H, da Silva MG. An integrated approach on energy consumption and indoor environmental quality performance in six Portuguese secondary schools. Energy Res Soc Sci 2017;32:23-43.

[20] Thewes A, Maas S, Scholzen F, Waldmann D, Zürbes A. Field study on the energy consumption of school buildings in Luxembourg. Energy Build 2014;68:460-70.

[21] Kim T-W, Lee K-G, Hong W-H. Energy consumption characteristics of the elementary schools in South Korea. Energy Build 2012;54:480-9.

[22] Dimoudi A, Kostarela P. Energy monitoring and conservation potential in school buildings in the $C^{\prime}$ climatic zone of Greece. Renew Energy 2009;34(1):289-96.
[23] Martinopoulos G, Kikidou V, Bozis D. Energy assessment of building physics principles in secondary education buildings. Energies 2018;11(11):2929.

[24] Hernandez P, Burke K, Lewis JO. Development of energy performance benchmarks and building energy ratings for non-domestic buildings: an example for Irish primary schools. Energy Build 2008;40(3):249-54.

[25] Sharp TR. Benchmarking energy use in schools. Proceedings of the ACEEE 1998 Summer Study on Energy Efficiency in Buildings. 1998. 3.

[26] Ballarini I, Corgnati SP, Corrado V. Use of reference buildings to assess the energy saving potentials of the residential building stock: the experience of TABULA project. Energy Policy 2014;68:273-84.

[27] Nikolaou T, Kolokotsa D, Stavrakakis G. Review on methodologies for energy benchmarking, rating and classification of buildings. Adv Build Energy Res 2011;5(1):53-70.

[28] Field J, Cibse T. Energy benchmarks. Chart Inst Build Serv Eng Lond 2008.

[29] Chung W, Hui YV, Lam YM. Benchmarking the energy efficiency of commercial buildings. Appl Energy 2006;83(1):1-14.

[30] Coakley D, Raftery P, Keane M. A review of methods to match building energy simulation models to measured data. Renew Sustain Energy Rev 2014;37:123-41.

[31] Li Z, Han Y, Xu P. Methods for benchmarking building energy consumption against its past or intended performance: an overview. Appl Energy 2014;124:325-34.

[32] Santamouris M, et al. Using intelligent clustering techniques to classify the energy performance of school buildings. Energy Build 2007;39(1):45-51.

[33] Gao X, Malkawi A. A new methodology for building energy performance benchmarking: an approach based on intelligent clustering algorithm. Energy Build 2014;84:607-16.

[34] Papadopoulos S, Bonczak B, Kontokosta CE. Pattern recognition in building energy performance over time using energy benchmarking data. Appl Energy 2018;221:576-86.

[35] Hong S-M, Paterson G, Mumovic D, Steadman P. Improved benchmarking comparability for energy consumption in schools. Build Res Inf 2014;42(1):47-61.

[36] Luo X, Hong T, Chen Y, Piette MA. Electric load shape benchmarking for small-and medium-sized commercial buildings. Appl Energy 2017;204:715-25.

[37] Park HS, Lee M, Kang H, Hong T, Jeong J. Development of a new energy benchmark for improving the operational rating system of office buildings using various datamining techniques. Appl Energy 2016;173:225-37.

[38] Marrone P, Gori P, Asdrubali F, Evangelisti L, Calcagnini L, Grazieschi G. Energy benchmarking in educational buildings through cluster analysis of energy retrofitting. Energies 2018;11(3):649.

[39] Torcelini P et al. DOE commercial building benchmark models. National Renewable Energy Lab (NREL), Golden, CO (United States); 2008.

[40] Attia S, Evrard A, Gratia E. Development of benchmark models for the Egyptian residential buildings sector. Appl Energy 2012;94:270-84.

[41] eurostat. Cooling and heating degree days by NUTS 2 regions - annual data; 2020.

[42] de Vasconcelos AB, Pinheiro MD, Manso A, Cabaço A. A Portuguese approach to define reference buildings for cost-optimal methodologies. Appl Energy 2015;140:316-28.

[43] Pagliano L, Carlucci S, Causone F, Moazami A, Cattarin G. Energy retrofit for a climate resilient child care centre. Energy Build 2016;127:1117-32.

[44] AGION. Pilootproject Passiefscholen Bilan 2015. AGION, Brussels; 2015.

[45] EFIKA. Strategienota Renovatie niet-residentiële gebouwen. Deurne; 2016.

[46] Cenergie. Rationeel energiegebruik: energiezorg in scholen. Vlaams Ministerie van Onderwijs en Vorming, Brussel; 2007.

[47] Marrecau, Christophe and Meyers, Kris. Passiefscholen. Vlaams Ministerie van Onderwijs en Vorming, Brussels, vol. 5; 2007

[48] AGION. Pilootproject Passiefscholen Bilan 2016-2017. AGION, Brussels; 2017.

[49] Abbeloos, Guillaume. Equipements Techniques d'une Ecole Passive. UCLouvain, Louvain La Neuve; 2011.

[50] Deprez, Bernard. Be.passive: schools. vol. 3; 2010. p. 92.

[51] AkkP 33. Passivhaus-Schulen, Protokollband Nr. 33 des Arbeitskreises kostengünstige Passivhäuser Phase III. Darmstadt: Passive House Institute; 2006.

[52] Moniteur Belge. Flemish Government Decree concerning energy performances in school buildings. In: Flemish: Belgisch Staatsblad, Besluit van de Vlaamse Regering tot regeling van een aantal aangelegenheden ter uitvoering van het decreet van 7 december 2007 betreffende energieprestaties in scholen, vol. 2007; 2008. p. 235.

[53] Passive House Institute. Passivhaus Projektierungspaket (PHPP) version 2007; 2007.

[54] Feist W, Schnieders J, Dorer V, Haas A. Re-inventing air heating: convenient and comfortable within the frame of the Passive House concept. Energy Build 2005;37(11):1186-203.

[55] Mlecnik E, Attia SGM, Van Loon S. Net zero energy building: a review of current definitions and definition development in Belgium. Passive house symposium 2011; vol. 1.

[56] Atanasiu B, Attia S. Principles for nearly zero-energy buildings: paving the way for effective implementation of policy requirements. Princ nearly zero-energy build paving way eff implement policy requir. 2011. p. 124.

[57] European Union. Education and training MONITOR 2019. Luxembourg: Publications Office of the European Union; 2019.

[58] Voigt P, Von dem Bussche A. The EU general data protection regulation (GDPR). Pract guide 1st ed. Cham Springer Int. Publ.; 2017.

[59] Beusker E, Stoy C, Pollalis SN. Estimation model and benchmarks for heating energy consumption of schools and sport facilities in Germany. Build Environ 2012;49:324-35.

[60] Gil-Baez M, Padura ÁB, Huelva MM. Passive actions in the building envelope to enhance sustainability of schools in a Mediterranean climate. Energy 2019;167:144-58.

[61] ASHRAE. International weather for energy calculations (IWEC Weather Files) user's 
manual and CD-ROM. ASHRAE Atlanta; 2001.

[62] Beck HE, Zimmermann NE, McVicar TR, Vergopolan N, Berg A, Wood EF. Present and future Köppen-Geiger climate classification maps at 1-km resolution. Sci Data 2018;5:180214.

[63] Krarti M. Energy audit of building systems: an engineering approach. CRC Press; 2016.

[64] DiLaura DL, Houser KW, Mistrick RG, Steffy GR. The lighting handbook: reference and application. Illuminating Engineering Society of North America New York; 2011.

[65] DOE. EnergyPlus. [Online]. Available: https://energyplus.net/ [accessed: 12-Dec2019].

[66] Guideline A. Guideline 14-2002, measurement of energy and demand savings. Am Soc Heat Vent Air Cond Eng Atlanta Ga 2002

[67] Hopfe CJ, Hensen JL. Uncertainty analysis in building performance simulation for design support. Energy Build 2011;43(10):2798-805.

[68] Causone F, Carlucci S, Moazami A, Cattarin G, Pagliano L. Retrofit of a kindergarten targeting zero energy balance. Energy Procedia 2015;78:991-6.

[69] Dhondt K. Average construction cost 'Schools of Tomorrow'; 14-Jun-2018.

[70] Ashrae AS. Standard 90.1-2004, Energy standard for buildings except low rise residential buildings. Am Soc Heat Refrig Air-Cond Eng Inc 2004

[71] Cen E. 15251: 2007 Indoor environmental input parameters for design and assessment of energy performance of buildings addressing indoor air quality, thermal environment, lighting and acoustics. Bruss Belg 2007.

[72] ter Mors S, Hensen JL, Loomans MG, Boerstra AC. Adaptive thermal comfort in primary school classrooms: creating and validating PMV-based comfort charts. Build Environ 2011;46(12):2454-61.

[73] CEN. Ventilation for non-residential buildings - performance requirements for ventilation and room-conditioning systems. CEN, Brussels; 2007.

[74] de Normalisation CE. EN 12464-1: light and lighting-lighting of work places, Part 1: Indoor work places. Com Eur Norm 2002.

[75] Srinivasan RS, et al. Benchmarking plug-load densities for K-12 schools. Proceedings of building simulation 2011, 12th conference of international building performance simulation association. 2011. p. 2746-52.

[76] ASHRAE. ASHRAE guideline 14-2002 measurement of energy and demand savings. ASHRAE; 2002.
[77] Loga T, Stein B, Diefenbach N. TABULA building typologies in 20 European countries-Making energy-related features of residential building stocks comparable. Energy Build 2016;132:4-12.

[78] Toleikyte A et al. ZEBRA 2020-Nearly zero-energy building strategy 2020. Strategies for a nearly Zero-Energy Building market transition in the European Union; 2016.

[79] Yang L, Yan H, Lam JC. Thermal comfort and building energy consumption implications-a review. Appl Energy 2014;115:164-73.

[80] Dasgupta A, Prodromou A, Mumovic D. Operational versus designed performance of low carbon schools in England: bridging a credibility gap. HVACR Res 2012;18(1-2):37-50.

[81] Niemelä T, Kosonen R, Jokisalo J. Cost-optimal energy performance renovation measures of educational buildings in cold climate. Appl Energy 2016;183:1005-20.

[82] Zomorodian ZS, Tahsildoost M, Hafezi M. Thermal comfort in educational buildings: a review article. Renew Sustain Energy Rev 2016;59:895-906.

[83] Liang H-H, Lin T-P, Hwang R-L. Linking occupants' thermal perception and building thermal performance in naturally ventilated school buildings. Appl Energy 2012;94:355-63.

[84] Attia S, Garat S, Cools M. Development and validation of a survey for well-being and interaction assessment by occupants in office buildings with adaptive facades. Build Environ 2019;157:268-76.

[85] Kern Handboek. nZEB-tool, voor het ontwerpen van een (nearly) Zero Energy Building. Ede, The Netherlands: Kennis Instituut Kern; 2019.

[86] Allaerts K, Al Koussa J, Desmedt J, Salenbien R. Improving the energy efficiency of ground-source heat pump systems in heating dominated school buildings: a case study in Belgium. Energy Build 2017;138:559-68.

[87] C. I. of B. S. Engineers. Integrated school design: CIBSE TM57: 2015. Chartered Institution of Building Services Engineers; 2015.

[88] Knight I, Lannon S, Iorwerth H. Welsh 2016 half-hourly building energy consumption profiles for domestic and non-domestic buildings by 2011 Census output area. Split by Local Authority Areas; 2017.

[89] Portier E. Passive building project sets the bar for greener schools. Flanders Today; 03-Nov-2016. [Online]. Available: http://www.flanderstoday.eu/education/ passive-building-project-sets-bar-greener-schools. 